\title{
Comprehensive Review on Electricity Market Price and Load Forecasting Based on Wind Energy
}

\author{
Hakan Acaroğlu ${ }^{1}$ (D) and Fausto Pedro García Márquez ${ }^{2, *(D)}$ \\ 1 Department of Economics, Faculty of Economics and Administrative Sciences, Eskisehir Osmangazi \\ University, Eskisehir 26480, Turkey; hacaroglu@ogu.edu.tr \\ 2 Ingenium Research Group, University of Castilla-La Mancha, 13004 Ciudad Real, Spain \\ * Correspondence: FaustoPedro.Garcia@uclm.es
}

Citation: Acaroğlu, H.; García Márquez, F.P. Comprehensive Review on Electricity Market Price and Load Forecasting Based on Wind Energy. Energies 2021, 14, 7473. https:// doi.org/10.3390/en14227473

Academic Editor: Yuji Yamada

Received: 7 October 2021

Accepted: 3 November 2021

Published: 9 November 2021

Publisher's Note: MDPI stays neutral with regard to jurisdictional claims in published maps and institutional affiliations.

Copyright: (c) 2021 by the authors. Licensee MDPI, Basel, Switzerland. This article is an open access article distributed under the terms and conditions of the Creative Commons Attribution (CC BY) license (https:/ / creativecommons.org/licenses/by/ $4.0 /)$.

\begin{abstract}
Forecasting the electricity price and load has been a critical area of concern for researchers over the last two decades. There has been a significant economic impact on producers and consumers. Various techniques and methods of forecasting have been developed. The motivation of this paper is to present a comprehensive review on electricity market price and load forecasting, while observing the scientific approaches and techniques based on wind energy. As a methodology, this review follows the historical and structural development of electricity markets, price, and load forecasting methods, and recent trends in wind energy generation, transmission, and consumption. As wind power prediction depends on wind speed, precipitation, temperature, etc., this may have some inauspicious effects on the market operations. The improvements of the forecasting methods in this market are necessary and attract market participants as well as decision makers. To this end, this research shows the main variables of developing electricity markets through wind energy. Findings are discussed and compared with each other via quantitative and qualitative analysis. The results reveal that the complexity of forecasting electricity markets' price and load depends on the increasing number of employed variables as input for better accuracy, and the trend in methodologies varies between the economic and engineering approach. Findings are specifically gathered and summarized based on researches in the conclusions.
\end{abstract}

Keywords: electricity price; electricity load; electricity price forecasting; wind energy; day-ahead market; intra-day market; balancing power market

\section{Introduction}

The government-controlled and monopolistic characteristics of the power sector has been changing since the beginning of the 1990s with the introduction of competitive market and deregulation processes [1]. The free-competitive market rules reshape electricity trade, as electricity is a non-storable commodity in economic terms, and its consumption and production require a balance dependent on power system stability $[2,3]$. In line with these changes, generating electricity from the renewable energy resources, mainly wind and solar powers, is rapidly increasing in the world $[4,5]$. This increase can be attributed to the environmentally friendly characteristics of renewable energy resources, that can be expressed by increasing energy demand triggering global warming in the world [6].

Energy demand can be supplied by electricity production through wind energy [7]. However, electricity production is affected by weather conditions (e.g., speed of wind, precipitation, and temperature) and industrial activities (e.g., business work hours, weekdays, holidays, weekends, etc.) [1,8]. These elements are particular to the electricity commodity, making it unique and different from other commodities in terms of forecasting related price dynamics. It leads to researchers developing new prediction methods. Besides, in both financial and academic institutions, electricity price forecasts (EPFs) have become a basic information for energy companies and energy researchers in their decision-making systems and agendas $[1,9,10]$. 
Various methods have been tried and developed for EPFs through renewable energy, and it will continue as the new techniques are studied [11]. A contribution of this paper to the literature is to analyze the relationship between EPF and wind energy. This paper presents, as scientific novelty, a review on recent trends of EPF techniques considering wind energy and updated references. The advances in EPF and load techniques are comparatively discussed, and it is concluded with the main future works to cover in:

- $\quad$ Short-term, middle-term, and long-term price and load forecasting approaches;

- Simulation, equilibrium, production cost and fundamental models for middle and long terms;

- Statistical, artificial intelligence, and hybrid models in the framework of time series for short terms;

- Moving trends of EPF and load techniques that are in the span of economics and engineering fields;

- Working principles of electricity markets through country-specific examples.

Forecasting methods in electricity market and renewable energy resources have gained a forward acceleration and attracted attention from market participants and decision makers [12]. To this end, the motivation of this paper is to present a comprehensive review for electricity markets considering price and load forecasting mechanisms through wind energy, which is one of the fastest growing renewable energy resources due to a growing wind power integration into the electrical grids [13]. For the determined hypothesis, it is observed that forecasting approaches vary between economic terms (i.e., demand [14], supply [15], profit [16], producer, and consumer surplus [17]) and engineering techniques (i.e., power systems [18,19], optimization [20], control [21], and meta-heuristics algorithms [22,23]). As a methodology, this review follows the historical and structural development of electricity markets (i.e., day-ahead markets, intra-day markets, balancing power markets), price and load forecasting methods, and recent trends in wind energy generation, transmission, and consumption, being a novel contribution to the literature. The difficulties of predicting wind power [24], i.e., wind power has a stochastic nature [25] and its prediction is contigent upon weather conditions, e.g., wind speed; precipitation; temperature, may have some adverse effects on the market operations such as fast fluctuations of wind power and loads in the new designed power grid [18]. Nonetheless, wind energy resource applications require extremely rigarous and accurate data [26].

Findings are discussed and compared through the use of quantitative and qualitative analysis, and they reveal that the complexity of forecasting electricity markets price and load depends on the increasing number of employed variables as input for better accuracy, and the trend in methodologies varies between the economic and engineering approaches, and specifically includes mathematics, statistics, econometrics, and electrical engineering and computer science.

The content of the work is presented as follows: Section 2 presents a literature analysis on electricity market mechanism, components, and instruments, considering the day-ahead market (DAM), or spot market; the intra-day market (IDM), or future market; the balancing power market (BPM), or balance market; price of electricity; and electric load. Section 3 shows the electricity market price and load forecasting through wind energy generation. Section 4 analyzes the forecasting models of the electricity markets through wind energy, where several case studies are considered and discussed.

\section{Electricity Market Mechanism, Components, and Instruments}

\subsection{Electricity Market: Structure and Components}

The short-term electricity market structure includes day-ahead and intraday markets which are often known as "spot markets" [27]. However, these markets' designs show differences. While DAMs have been coupled for the last few years, IDMs have gained traction by going global from being national [28]. Moreover, DAMs are organized as auctions, whereas IDMs operate as trades and enable market participants to balance demand and supply variations in the short-term to decrease exposure to an imbalance penalty [28,29]. 
The reason being, DAMs are based on forecasts and forecasts include errors in their nature. Specifically, various and increasing number of parameters, intermittent production from wind power plants can be given as the factors. However, the closer to real-time, the more accurate the forecast is possible. The bilateral basis with continuous trading enables market participants to adjust their last updated positions [27]. In addition to these markets, the eventual balancing of the supply and demand is accomplished by the BPMs, which are regulated by the transmission system operator (TSO). The system stability is provided in the context of security in these markets [30] (see [31,32] for detailed information).

\subsubsection{Day-Ahead Markets}

DAMs are organized markets that are used for electricity trading and balancing activities just one day before the delivery date of electricity, operated by a transmission system operator. DAMs include auctions that are conducted simultaneously $24 \mathrm{~h}$ in a day. The market participants are able to adjust their own transaction schedule by selling or buying power with the short-term price forecasts thereby maximizing their profits [33]. The main reasons that DAMs are needed and their purposes are summarized as follows [34]:

- Determining the electrical energy reference price.

- To provide market participants with the opportunity to balance themselves by giving them selling and buying energy options for the next day in addition to their bilateral agreements.

- To provide the system operator with a balanced system the day before.

- To provide the system operator with the opportunity to manage the constraints in the day before, by creating bid zones for large-scale and continuous constraints.

DAMs are developing through institutions, regulations, software and web applications daily. For instance, currently, a DAM software and optimization model on the DAM for the Turkish electricity sector, which has a user-friendly interface design and is amenable to flexibility and improvements, since it is designed and written entirely by the domestic resources, has been completed [35]. Table 1 shows the various DAMs electricity markets over the world.

Table 1. Various DAMs in the world.

\begin{tabular}{cc}
\hline Country & Name (Year) \\
\hline UK & England and Wales Electricity Pool (1990) \\
Norway & Nord Pool (1992) \\
Sweden & Nord Pool (1996) \\
Spain & (OMEL) (1998) \\
Finland & Nord Pool (1998) \\
USA & California Power Exchange (CalPX) (1998) \\
Netherlands & Amsterdam Power Exchange (APX) (1999) \\
USA & New York ISO (NYISO) (1999) \\
Germany & Leipzig Power Exchange (LPX) (2000) \\
Germany & European Energy Exchange (EEX) (2000) \\
Denmark & Nord Pool (2000) \\
Poland & Powarowa Gielda Energii (Polish Power Exchange, \\
USA & PolPX) (2000) \\
& Interconnection (2000) \\
\hline
\end{tabular}


Table 1. Cont.

\begin{tabular}{cc}
\hline Country & Name (Year) \\
\hline UK & UK Power Exchange (UKPX) (2001) \\
UK & Automated Power Exchange (APX UK) (2001) \\
Slovenia & Borzen (2001) \\
France & Powernext (2002) \\
Austria & Energy Exchange Austria (EXAA) (2002) \\
USA & ISO New England (2003) \\
Italy & Italian Power Exchange (IPEX) (2004) \\
Chez Republic & Operator Trhu s Electrinou (OTE) (2004) \\
USA & Midwest ISO (MISO) (2005) \\
Belgium & Belgian Power Exchange (Belpex) (2006) \\
\hline Source: Adapted from [1]. &
\end{tabular}

The liberalization of the electricity markets in Europe began three decades ago [36]. Before the 1990s, the markets had a monopolistic characteristic and were dictated by governments. This transformation led to electricity generation, transmission and distribution along with the law of supply/demand, which enabled competition and price reductions [37]. It is noteworthy that the DAMs in the world have adapted to this transformation and quickly became larger markets, and some of their names that are mentioned in Table 1 changed due to integrations, where detailed information can be found in [1].

\subsubsection{Intra-Day Markets}

In addition to the currently operating DAM, Ancillary Services, and balancing power market, the intra-day market (IDM) enables near real-time trading and offers market participants the opportunity to balance their portfolios in the short term. The IDM works as a bridge between the DAM and the BPM, and it contributes greatly to sustainability of the whole system.

The functionality of the IDM changes the role of the factors that cause imbalances, such as power plant failures, changes in the production of renewable energy sources, and unpredictable changes in the amount of consumption, as they will be eliminated in a near real time, and the participants will be given the opportunity to balance or minimize the negative or positive imbalances that they may face. Additional trading space will be provided by giving the participants the chance to evaluate their capacities, which they cannot use in the DAM, in the IDM after the closing time of the DAM. It will contribute to the increase of liquidity in the markets. It will also be of significant assistance to the TSO in providing a balanced system prior to real-time balancing.

IDMs are developing daily in terms of institutions, regulations, software, and web applications. The market designs in IDM might strongly deviate between countries [38]. For instance, a new software, named "Intraday Market Software", on IDM for the Turkish electricity sector was developed and has been in use by Energy Exchange Istanbul (EPIAS) since 2016 [39]. More information can be found in [40] for the German IDM, in [41] for the European IDM, and in [42] for the Swedish IDM.

\subsubsection{Balancing Power Markets (Balance Markets)}

Real-time balancing consists of balancing power market (BPM) and ancillary services. The system operator is provided the spare capacity that can be activated in a couple of minutes (i.e., around $15 \mathrm{~min}$ ) by the BPM for real-time balancing. Ancillary services provide demand and frequency control services. The balancing market prices are determined hourly based on upward and downward regulating power offers evaluated by the TSO in real-time balancing [43].

Although a market with balanced production and consumption amounts is given to the TSO with the DAM and IDM, there are deviations in real time. For example, if a power 
plant is out of service, or when a large amount of consumption causes the plant to stop (start), the balance is disrupted [44]. For instance, on BPM for Turkish electricity sector [45]:

- All market participants participating in the BPM must present their available capacities.

- Balancing units that can receive or load independently in a couple of minutes (around $15 \mathrm{~min}$ ) are obliged to engage in the BPM.

More information can be found in [46] for the European BPMs.

\subsection{Electricity Market Instruments through Country-Specific Researches}

\subsubsection{Electricity Price}

Electricity prices, or market clearing price (MCP), are determined by the law of supply/demand curves. The place for this is the DAM, which is managed by the system operators of the countries. The system operators gather hourly offers for the following day from sellers and buyers, and the supply/demand curves are analytically built in this way. The intersection of the supply and demand curves gives the MCP. While the buying and selling amounts are named as equilibrium quantities of electricity, the electricity trade volume is determined by multiplication of the equilibrium quantity and MCP. However, forecasting electricity prices is not easy because price series show characteristics such as variance, nonconstant mean, significant outliers, and volatility [47]. The common characteristics of electricity prices can be summarized as follows [1,48,49]:

- Seasonal effects for prices;

- Mean reversion;

- Spikes and volatilities due to changes in fuel price, load uncertainty, outages, market power, and market participant's behavior;

- Correlation between electricity load and price.

More detailed information can be found in [1] for various countries, and in [50] for the Turkish electricity markets, in [51] for the England and Wales electricity markets, in [52,53] for the Nordic electricity (Nord Pool) markets, in [54] for the New Zealand electricity markets, in [55] for Danish electricity markets, and in [56] for the US electricity markets.

\subsubsection{Electricity Load}

Forecasting the electricity load has been a key role in the operation of power systems, and it includes forecasts on various time scales (i.e., minutely, hourly, and yearly) [57]. Several decisions are based on load forecasts, for instance, reliability analysis, dispatch planning of generating capacity, and operation and maintenance plans for power systems. With the free competition and deregulation of the electric power industry, load forecasting increased its viability and importance all around the world. An accurately predicted load is vital data for the EPF, since market shares, profits, and shareholder value can easily be influenced by forecast errors. Nevertheless, due to the nonstationary and variability of the load series, forecasting procedures of the electric load is increasingly difficult. Timevarying prices, price-dependent loads, and the dynamic bidding strategies of market participants make this complexity [58]. Therefore, more accurate results are needed by more sophisticated forecasting instruments for the electrical power systems and the motivation behind more accurate forecast methods is hidden in the economic effect of the forecast errors [59]. However, a substantial amount of research has been done (see $[60,61]$ for reviews and $[58,62,63]$ for methods and techniques of short-term load forecasting and modeling, respectively).

Moreover, electric power should be stored or consumed very close-after from its generation. The cost of storing electric power is expensive, therefore, electricity markets, through system operators, exist for allocating the transactions between market participants. This mechanism provides a possible distribution of loads, freeing networks will be avoided from excessive loads. This review is focused on renewable energy through wind energy. Weather conditions, e.g., wind speed, precipitation, and temperature, have an important influence on electricity production from wind energy. The countries that supply a considerable share 
of electricity demand from wind energy (e.g., Spain, Denmark, Germany [4]) and have wind energy potential (e.g., Turkey) should consider this energy source, mitigating global warming. More details can be found in [1] for various countries, and in [50] for the Turkish electricity markets.

\section{Electricity Market Price and Load Forecasting through Wind Energy Production}

The EPF studies can be categorized in the following two main groups: Long/middle terms and short terms. While long/middle models can be gathered into: simulation, equilibrium, production cost, and fundamental models. Short term models, or time series models, can be gathered into: statistical, artificial intelligence, and hybrid models [64], see Figure 1. This review paper follows the approach presented in [64]. Tables 2 and 3 presents a literature review through statistical models. However, it differs from the mentioned approach by merging the artificial intelligence and hybrid models into one category, as shown in Table 4 . Table 5 presents a literature review through middle/long term models on electricity market price and load forecasting through wind energy.

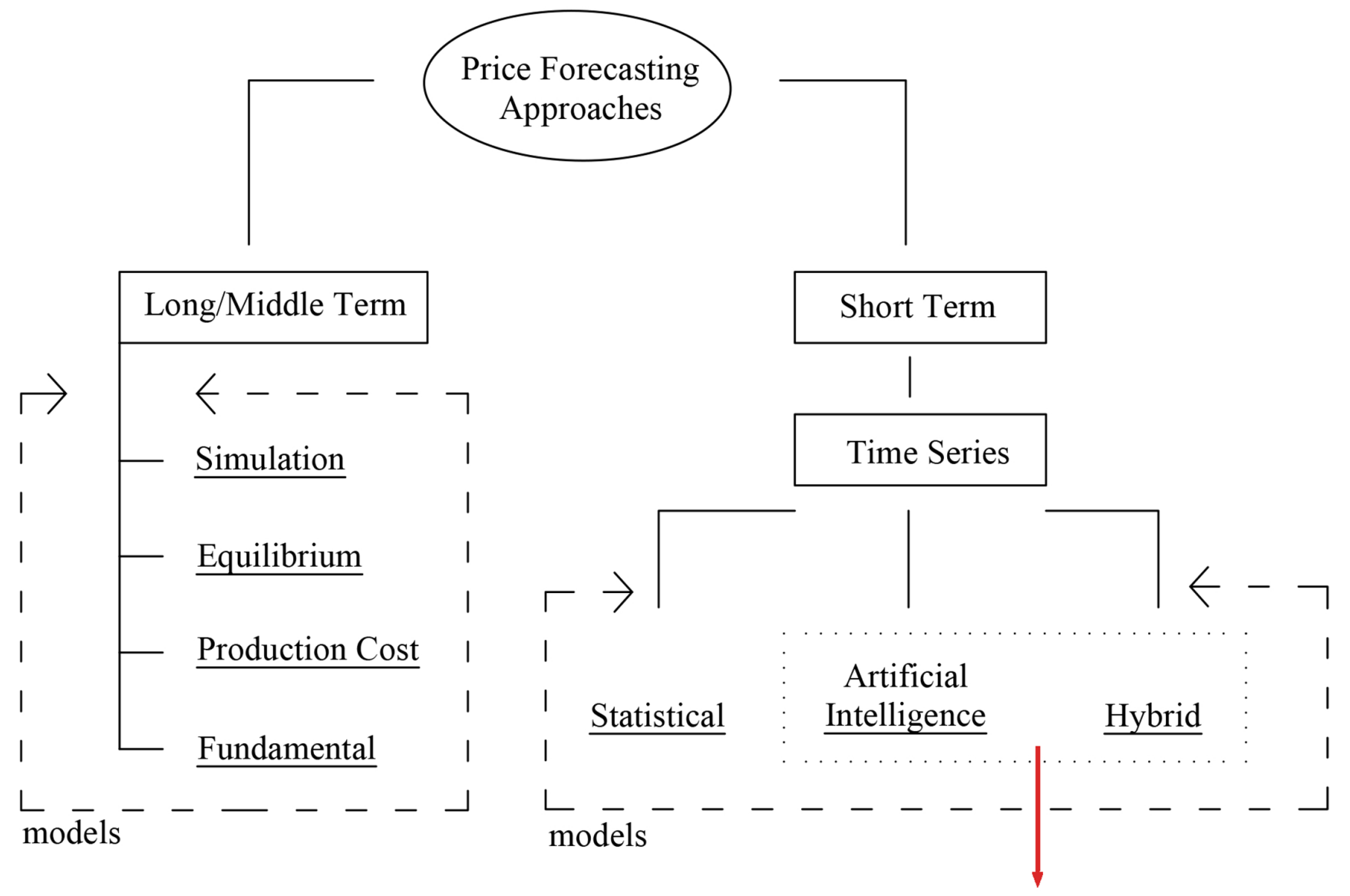

Artificial Intelligence and Hybrid models are gathered in one table in this study.

Figure 1. A classification for EPF approaches. Source: Adapted from [64].

Various statistical model examples are shown in Tables 2 and 3 (Table 2 contains more simple models, represents the first part of the statistical models and Table 3 contains more advanced models, represents the second part of the statistical models). These models can be gathered in a main title named as time series analysis. Specifically, ordinary least squares (OLS) regressions, autoregressive distributed lag (ARDL) regressions, panel data analysis, vector autoregressive (VAR) analysis, generalized autoregressive conditional heteroskedasticity $(\mathrm{GARCH})$ analysis, multiple linear regressions, auto-regressive with eXternal model 
input (ARX) analysis, logit-probit regressions, quantile regressions, autoregression (AR) models, exponential generalized autoregressive conditional heteroskedasticity (eGARCH) analysis, autoregressive moving average model with exogenous regressors (ARMAX) analysis, least absolute shrinkage and selection operator (LASSO) analysis, seasonal component autoregressive (SCAR) analysis, and univariate and multivariate regressions.

The studies concentrating on merit-order effect for wind power on electricity market price are viable among researchers. Positive merit order effects were found with OLS analysis and time series regressions for Italy [31,65] and for US (California) [66], with time series analysis for Australia [67], and Germany [68], and with ARDL model and demand/supply framework for Australia [69,70], and with quantile regression model for Germany [71] and for US (California) [72]. A different type of time series analysis with panel data analysis through fixed effect regression was applied in [31] for Germany, and a dampening effect of wind power with reduced forecasting errors, which led to decreased price volatility. The VAR model was applied in [42] for Sweden with Granger causality analysis (i.e., unit root tests and impulse-response functions), and it was shown that the prices in the IDMs responded to wind power forecast errors. The same model was applied in [73] for Denmark, Sweden, and Finland. It was found that wind forecast errors did not affect price spreads in locations with large amounts of wind power generation. Studies for Germany [74,75] and Australia [76] with GARCH and eGARCH models showed that an increase in wind generation decreased the prices and increased the price volatility. A multiple linear regression model was applied for Germany's electricity markets [32,77], which showed that 15 min scale helped significantly to reduce imbalances in intraday trading, and a considerable share of spot price variance was explained by fundamental modelling. The ARX models, which are linear models, were applied for Germany [30,78], Poland [78], European countries, and the US [79], and the findings supported more accurate EPPs in the mentioned electricity markets. The ARMAX model was applied for Germany, where it showed that wind energy generation decreased market spot prices [80]. The AR models were applied for Denmark, Finland, Norway, and Sweden, and the used models were better performed compared to commonly-used EPF models [81,82]. The LASSO models were applied for Denmark, Finland, Norway, and Sweden, Germany, and the European Countries, and they demonstrated that LASSO models lead to better performance compared to the typically considered EPF models [83-85]. The SCAR models were applied for Denmark, Finland, Norway, and Sweden, where the SCAR models significantly outperformed the autoregressive benchmark [86]. The multivariate and univariate models were applied for the European countries and some guidelines were provided to structuring better performing models [87].

Table 2. Statistical models (first-part) on electricity market price and load forecasting through wind energy.

\begin{tabular}{|c|c|c|c|c|}
\hline Author (s) & Data/Period & Country & Method (s) & Findings \\
\hline Clo et al. (2015), [65]. & GME/2005-2013 & Italy & $\begin{array}{l}\text { Time series } \\
\text { (OLS) analysis }\end{array}$ & $\begin{array}{l}\text { The merit-order effect for wind } \\
\text { power was found. }\end{array}$ \\
\hline Cludius et al. (2014a), [67]. & $\begin{array}{c}\text { AEMO/ } \\
2011-2013\end{array}$ & Australia & $\begin{array}{c}\text { Time series } \\
\text { regression analysis }\end{array}$ & $\begin{array}{l}\text { The merit-order effect for wind } \\
\text { power was found. }\end{array}$ \\
\hline Cludius et al. (2014b), [68]. & EEX/2008-2016 & Germany & $\begin{array}{l}\text { Time series } \\
\text { regression analysis }\end{array}$ & $\begin{array}{l}\text { The merit-order effect for wind } \\
\text { power was found. }\end{array}$ \\
\hline Csereklyei et al. (2019), [69]. & NEM/2010-2018 & Australia & ARDL model & $\begin{array}{l}\text { The merit-order effect for wind } \\
\text { power was found. }\end{array}$ \\
\hline $\begin{array}{l}\text { Forrest and MacGill } \\
\qquad(2013),[70] .\end{array}$ & $\begin{array}{l}\text { AEMO and } \\
\text { NEM / 2009-2011 }\end{array}$ & Australia & $\begin{array}{l}\text { Econometric analysis } \\
\text { techniques (a } \\
\text { supply/demand } \\
\text { analysis for } \\
\text { electricity markets) }\end{array}$ & $\begin{array}{l}\text { The merit-order effect for wind } \\
\text { power was found and wind } \\
\text { generation had an impact on } \\
\text { the MCPs. }\end{array}$ \\
\hline
\end{tabular}


Table 2. Cont

\begin{tabular}{ccccc}
\hline Author (s) & Data/Period & Country & Method (s) & Findings \\
\hline Gianfreda et al. (2016), [31]. & ENTSO-E/ & Italy & $\begin{array}{c}\text { Time series } \\
\text { regression analysis }\end{array}$ & $\begin{array}{c}\text { It was found that wind generation } \\
\text { power induced high } \\
\text { imbalance values. }\end{array}$
\end{tabular}

Gürtler et al. (2018), [88] ENTSO-

E/2010-2016 Germany

Panel data analysis (fixed effect regression)

It was found that there were dampening effects of wind power on MCPs, however this effect started to decrease after 2013.

\begin{tabular}{|c|c|c|c|c|}
\hline Hu et al. (2018), [42]. & $\begin{array}{l}\text { Nord Pool FTP } \\
\text { server and } \\
\text { ENTSO- } \\
\text { E/2015-2018 }\end{array}$ & Sweden & $\begin{array}{l}\text { VAR framework } \\
\text { (Granger causality tests } \\
\text { and impulse } \\
\text { response functions) }\end{array}$ & $\begin{array}{l}\text { It was found that intraday prices } \\
\text { responded to wind power } \\
\text { forecast errors. }\end{array}$ \\
\hline Koch and Hirth, (2019), [32]. & $\begin{array}{l}\text { ENTSO-E and } \\
\text { TSO/2012-2017 }\end{array}$ & Germany & $\begin{array}{l}\text { A multiple linear } \\
\text { regression model }\end{array}$ & $\begin{array}{l}\text { It was shown that the } 15 \text { min scale } \\
\text { became common in intraday } \\
\text { trading and helped significantly to } \\
\text { reduce imbalances. }\end{array}$ \\
\hline Maciejowska (2020), [71]. & $\begin{array}{l}\text { EPEX and } \\
\text { ENTSO-E/ } \\
2015-2018 \\
\end{array}$ & Germany & $\begin{array}{l}\text { Quantile regression } \\
\text { model }\end{array}$ & $\begin{array}{l}\text { It was found that wind energy } \\
\text { generations had a negative effect } \\
\text { on the MCPs. }\end{array}$ \\
\hline Pape et al. (2016), [77]. & $\begin{array}{l}\text { ENTSO-E, EEX, } \\
\text { EPEX/2012-2013 }\end{array}$ & Germany & $\begin{array}{l}\text { Multiple linear } \\
\text { regression models } \\
\text { (Fundamental } \\
\text { price modeling) }\end{array}$ & $\begin{array}{c}\text { It was shown that the used models } \\
\text { well explained the spot } \\
\text { price variance. }\end{array}$ \\
\hline Serafin et al. (2019), [89]. & $\begin{array}{l}\text { Nord Pool, } \\
\text { PJM/2013-2018 }\end{array}$ & $\begin{array}{l}\text { Denmark, } \\
\text { Finland, } \\
\text { Norway, } \\
\text { and Sweden }\end{array}$ & $\begin{array}{l}\text { Quantile Regression } \\
\text { Averaging and } \\
\text { Quantile Regression } \\
\text { Machine }\end{array}$ & $\begin{array}{l}\text { It was shown that QRM was both } \\
\text { more efficient and had more } \\
\text { accurate distributional predictions. }\end{array}$ \\
\hline Spodniak et al. (2021), [73]. & $\begin{array}{l}\text { ENTSO-E, Nord } \\
\text { Pool/2015-2017 }\end{array}$ & $\begin{array}{l}\text { Denmark, } \\
\text { Sweden, } \\
\text { and Finland }\end{array}$ & VAR model & $\begin{array}{l}\text { It was found that wind forecast } \\
\text { errors had no impact on price } \\
\text { spreads in locations with a big } \\
\text { amount of wind power generation. }\end{array}$ \\
\hline Westgaard et al. (2021), [72]. & $\begin{array}{c}\text { LCG } \\
\text { Consulting, } \\
\text { OASIS/ } \\
2013-2016 \\
\end{array}$ & $\begin{array}{c}\text { US } \\
\text { (California) }\end{array}$ & Quantile regression & $\begin{array}{l}\text { Wind generation had a negative } \\
\text { effect on electricity prices. }\end{array}$ \\
\hline Woo et al. (2016), [66]. & $\begin{array}{l}\text { CAISO/ } \\
2012-2015\end{array}$ & $\begin{array}{c}\text { US } \\
\text { (California) }\end{array}$ & OLS Regression & $\begin{array}{l}\text { It was found that trading } \\
\text { efficiency could be enhanced by } \\
\text { DAM forecasts. }\end{array}$ \\
\hline Ziel and Steinert, (2018a), [90]. & EPEX/2012-2015 & $\begin{array}{l}\text { Germany } \\
\text { and Austria }\end{array}$ & $\begin{array}{l}\text { Time series models } \\
\text { (supply/demand } \\
\text { curves) }\end{array}$ & $\begin{array}{l}\text { It was found that using the law of } \\
\text { supply/demand curve yields } \\
\text { realistic patterns for electricity } \\
\text { prices and leads to } \\
\text { promising results. }\end{array}$ \\
\hline Ziel and Weron, (2018b), [87]. & $\begin{array}{l}\text { EPEX, Nord } \\
\text { Pool, BELPEX/ } \\
2011-2013\end{array}$ & $\begin{array}{l}\text { European } \\
\text { Countries }\end{array}$ & $\begin{array}{l}\text { Multivariate and } \\
\text { univariate models. }\end{array}$ & $\begin{array}{l}\text { More powerful variables identified } \\
\text { and guidelines were provided for } \\
\text { better performing models. }\end{array}$ \\
\hline \multicolumn{3}{|c|}{$\begin{array}{l}\text { AEMO: Australia Energy Market Operator } \\
\text { ARDL: Autoregressive distributed lag models } \\
\text { BELPEX: EPEX Spot Belgium } \\
\text { DAM: Day-ahead market } \\
\text { EEX: The European Energy Exchange } \\
\text { E: European Network of Transmission System Operators } \\
\text { for Electricity }\end{array}$} & $\begin{array}{l}\text { EPEX: The European } \\
\text { Power Exchange } \\
\text { GME: Gestore dei } \\
\text { Mercati Energetici } \\
\text { MCPs: Market } \\
\text { clearing prices } \\
\text { NEM: The Australian } \\
\text { National Electricity } \\
\text { Market's }\end{array}$ & $\begin{array}{c}\text { PJM: The Pennsylvania-New } \\
\text { Jersey-Maryland Interconnection } \\
\text { OLS: Ordinary least squares } \\
\text { QRM: Quantile } \\
\text { regression machine } \\
\text { VAR: The vector autoregressive }\end{array}$ \\
\hline
\end{tabular}


Table 3. A literature review through statistical models (second-part) on electricity market price and load forecasting through wind energy.

\begin{tabular}{|c|c|c|c|c|}
\hline Author (s) & Data/Period & Country & Method (s) & Findings \\
\hline Ketterer (2014), [74]. & $\begin{array}{c}\text { EEX and } \\
\text { ENTSO-E/2006-2012 }\end{array}$ & Germany & GARCH model & $\begin{array}{l}\text { Wind power generation had a } \\
\text { positive effect on decreasing the } \\
\text { wholesale electricity price; } \\
\text { however, increased its volatility. }\end{array}$ \\
\hline Kyritsis et al. (2017), [75]. & $\begin{array}{l}\text { Phelix Day } \\
\text { Base, EEX, } \\
\text { and ENTSO-E/ } \\
\text { 2010-2015 }\end{array}$ & Germany & $\begin{array}{l}\text { GARCH-in-Mean } \\
\text { model }\end{array}$ & $\begin{array}{l}\text { It was found that wind power } \\
\text { Granger cause of MCPs and the } \\
\text { volatility of electricity prices were } \\
\text { increased by wind } \\
\text { power generation }\end{array}$ \\
\hline $\begin{array}{l}\text { Maciejowska et al. } \\
\text { (2019), [78]. }\end{array}$ & $\begin{array}{l}\text { TGE, PSE, EPEX } \\
\text { SPOT and ENTSO- } \\
\text { E/2016-2017 }\end{array}$ & $\begin{array}{l}\text { Germany } \\
\text { and Poland }\end{array}$ & $\begin{array}{l}\text { Econometric models } \\
\text { (i.e., ARX and probit) }\end{array}$ & $\begin{array}{l}\text { It was shown that the price spread } \\
\text { could be forecasted by ARX and } \\
\text { probit models. }\end{array}$ \\
\hline $\begin{array}{l}\text { Maciejowska et al. } \\
\text { (2021), [30]. }\end{array}$ & $\begin{array}{l}\text { EPEX and ENTSO- } \\
\text { E/2015-2019 }\end{array}$ & Germany & $\begin{array}{l}\text { Econometric models } \\
\text { (ARX) }\end{array}$ & $\begin{array}{l}\text { It was shown that variables that } \\
\text { were forecasted gave biased } \\
\text { results; however, they could be } \\
\text { corrected with regression models. }\end{array}$ \\
\hline Marcjasz et al. (2018), [81]. & $\begin{array}{l}\text { Nord Pool, PJM } \\
\text { Interconnection and } \\
\text { EPEX/2013-2018 }\end{array}$ & $\begin{array}{c}\text { Denmark, } \\
\text { Finland, } \\
\text { Norway, } \\
\text { and Sweden }\end{array}$ & Autoregression Models & $\begin{array}{l}\text { It was the extended model of } \\
\text { Hubicka et al. (2019), [91] analysis } \\
\text { with much longer datasets. }\end{array}$ \\
\hline $\begin{array}{l}\text { Mwampashi et al. } \\
\text { (2021), [76]. }\end{array}$ & NEM/2011-2020 & Australia & eGARCH model & $\begin{array}{l}\text { It was found that wind generation } \\
\text { increase decreased daily prices } \\
\text { and increased price volatility }\end{array}$ \\
\hline $\begin{array}{l}\text { Nowotarski et al. } \\
\text { (2014), [79]. }\end{array}$ & $\begin{array}{c}\text { Nord Pool, EEX, } \\
\text { and PJM/1998-2012 }\end{array}$ & $\begin{array}{l}\text { European } \\
\text { Countries } \\
\text { and US }\end{array}$ & $\begin{array}{c}\text { ARX model } \\
\text { (Constrained least } \\
\text { squares regression) }\end{array}$ & $\begin{array}{l}\text { The findings supported more } \\
\text { accurate results and the used } \\
\text { models were well performed for } \\
\text { EPFs in the electricity markets. }\end{array}$ \\
\hline Paraschiv et al. (2014), [80]. & $\begin{array}{l}\text { EEE, TSO, } \\
\text { Bloomberg/ } \\
\text { 2010-2013 }\end{array}$ & Germany & ARMAX model & $\begin{array}{l}\text { It was found that wind energy } \\
\text { generation decreased market spot } \\
\text { prices. }\end{array}$ \\
\hline $\begin{array}{l}\text { Uniejewski et al. } \\
\text { (2016), [82]. }\end{array}$ & $\begin{array}{l}\text { GEFCom, Nord } \\
\text { Pool/2011-2013 }\end{array}$ & $\begin{array}{l}\text { Denmark, } \\
\text { Finland, } \\
\text { Norway, } \\
\text { and Sweden } \\
\end{array}$ & $\begin{array}{l}\text { Autoregression (ridge } \\
\text { regression; stepwise } \\
\text { regression, LASSO; } \\
\text { elastic net) models }\end{array}$ & $\begin{array}{l}\text { The used models performed well } \\
\text { in comparison to previous } \\
\text { preferred EPF models. }\end{array}$ \\
\hline $\begin{array}{l}\text { Uniejewski and Weron } \\
\text { (2018), [83]. }\end{array}$ & $\begin{array}{c}\text { Nord Pool, } \\
\text { PJM/2013-2017 }\end{array}$ & $\begin{array}{l}\text { Denmark, } \\
\text { Finland, } \\
\text { Norway, } \\
\text { and Sweden }\end{array}$ & LASSO models & $\begin{array}{l}\text { It was shown that LASSO models } \\
\text { performed well in comparison to } \\
\text { previous preferred EPF models. }\end{array}$ \\
\hline $\begin{array}{l}\text { Uniejewski et al. } \\
\text { (2019a), [86]. }\end{array}$ & $\begin{array}{l}\text { GEFCom, Nord } \\
\text { Pool/2013-2015 }\end{array}$ & $\begin{array}{l}\text { Denmark, } \\
\text { Finland, } \\
\text { Norway, } \\
\text { and Sweden }\end{array}$ & SCAR models & $\begin{array}{l}\text { SCAR models significantly } \\
\quad \text { outperformed the } \\
\text { autoregressive benchmark. }\end{array}$ \\
\hline $\begin{array}{l}\text { Uniejewski et al. } \\
\text { (2019b), [84]. }\end{array}$ & EPEX/2015-2018 & Germany & LASSO models & $\begin{array}{c}\text { Some recommendations were } \\
\text { provided for very short-term EPF } \\
\text { with LASSO models. }\end{array}$ \\
\hline Ziel, (2016), [85]. & EPEX/2009-2014 & $\begin{array}{l}\text { European } \\
\text { Countries }\end{array}$ & $\begin{array}{l}\text { Time series model } \\
\text {-Linear regression } \\
\text { (LASSO) }\end{array}$ & $\begin{array}{l}\text { It was shown that the LASSO } \\
\text { forecasting technique } \\
\text { performed well. }\end{array}$ \\
\hline
\end{tabular}


Table 3. Cont

\begin{tabular}{|c|c|c|}
\hline Data/Period & Method (s) & Findings \\
\hline & $\begin{array}{c}\text { ENTSO-E: European } \\
\text { Network of }\end{array}$ & \\
\hline ARMAX: Autoregressive moving average model with & Transmission System & \\
\hline exogenous regressors & Operators & NEM: The Australian National \\
\hline ARX: Auto-regressive with eXternal model input & for Electricity & Electricity Market's \\
\hline EEX: The European Energy Exchange & EPEX: The European & PJM: The Pennsylvania-New \\
\hline \multirow{5}{*}{$\begin{array}{c}\text { GARCH: A generalized autoregressive conditional } \\
\text { heteroskedasticity model } \\
\text { eGARCH: An exponential generalized autoregressive conditional } \\
\text { heteroskedasticity) model }\end{array}$} & Power Exchange & Jersey-Maryland Interconnection \\
\hline & EPF: Electricity & SCAR: The Seasonal Component \\
\hline & price forecasting & AutoRegressive \\
\hline & LASSO: The least & \\
\hline & $\begin{array}{l}\text { absolute shrinkage and } \\
\text { selection operator }\end{array}$ & \\
\hline
\end{tabular}

The first part of the statistical models that are shown in Table 2 are closer to the research perspective of the fields of economics, and the traditionally used regression models by OLS (i.e., the difference between actual and predicted values are squared), VAR (i.e., the causality relationships), quantile regressions (i.e., the nonlinear relationships between electricity prices and variables are possible), and univariate and multivariate models (i.e., multivariate models are accepted as more accurate than the univariate ones but each approaches have its own advantages or disadvantages). However, when the number of regressors become large, these models were insufficient and, thereby, linear models via LASSO [92], ARX [93], SCAR (introduced by [94] and built on the ARX framework), GARCH [95-98] and eGARCH (i.e., proposed by [99]), and ARMAX [100] models were preferred, as it is shown in the second part of the statistical models with Table 3. Therefore, to obtain more accurate findings, statistical models should be more advanced and, since the complexity increases, artificial intelligence and hybrid models are required for more accurate and sensitive forecasts that are shown in Table 4 . However, this time the subject becomes closer to the research perspective of the engineering field.

Various artificial intelligence and hybrid/ensemble models on electricity market price and load forecasting through wind energy examples are shown in Table 4. These models can be gathered in a main title named as time series analysis. Specifically, ensemble learning methods for Austria [101], deep neural networks analysis for Germany [102] and US (New York) [103], sensitivity analysis for Mexico [104], and deep learning models for US (New York) [105] can be given as country-specific examples. General findings for the studies showed that the proposed method could provide an effective forecast.

Table 4. A literature review through artificial intelligence and hybrid/ensemble models on electricity market price and load forecasting through wind energy.

\begin{tabular}{|c|c|c|c|c|}
\hline Author (s) & Data/Period & Country & Method (s) & Findings \\
\hline $\begin{array}{l}\text { Bhatia et al. } \\
\text { (2021), [101]. }\end{array}$ & $\begin{array}{c}\text { ENTSO- } \\
\text { E/2015-2016 }\end{array}$ & Austria & $\begin{array}{l}\text { A real-time hourly } \\
\text { resolution model } \\
\text { (ensemble } \\
\text { learning model) }\end{array}$ & $\begin{array}{l}\text { The developed forecasting model } \\
\text { showed more consistency, } \\
\text { accuracy, and validity. }\end{array}$ \\
\hline $\begin{array}{l}\text { Bublits et al. } \\
(2017), \text { [106]. }\end{array}$ & $\begin{array}{l}\text { EPEX, ENTSO- } \\
\text { E/2011-2015 }\end{array}$ & Germany & $\begin{array}{l}\text { Agent based modelling } \\
\text { and multiple } \\
\text { regression analysis }\end{array}$ & $\begin{array}{l}\text { The effect of renewable energy } \\
\text { prices has been as half low as the } \\
\text { coal and carbon prices on } \\
\text { electricity prices in Germany in } \\
\text { the duration of analysis. }\end{array}$ \\
\hline $\begin{array}{l}\text { Li and Becker } \\
\text { (2021), [102]. }\end{array}$ & $\begin{array}{c}\text { Nord Pool, } \\
\text { ENTSO-E, } \\
\text { Thomson Reuters } \\
\text { Eikon/2015-2019 }\end{array}$ & Germany & $\begin{array}{c}\text { LSTM deep } \\
\text { neural networks }\end{array}$ & $\begin{array}{l}\text { It was shown that feature selection } \\
\text { is useful for more } \\
\text { accurate forecasts. }\end{array}$ \\
\hline
\end{tabular}


Table 4. Cont.

\begin{tabular}{|c|c|c|c|c|}
\hline Author (s) & Data/Period & Country & Method (s) & Findings \\
\hline May et al. (2022), [104]. & $\begin{array}{c}\text { CONAGUA, } \\
\text { CENACE, AND } \\
\text { CRE/2017-2018 }\end{array}$ & Mexico & $\begin{array}{c}\text { Artificial Intelligence } \\
\text { Techniques (Sensitivity } \\
\text { Analysis) }\end{array}$ & $\begin{array}{l}\text { It was found that the effects of the } \\
\text { variables fluctuated due to } \\
\text { consumption market conditions. }\end{array}$ \\
\hline $\begin{array}{l}\text { Nowotarski and Weron, } \\
\text { (2018), [107]. }\end{array}$ & GEFCom/2011-2013 & - & $\begin{array}{c}\text { Neural network and } \\
\text { autoregression }\end{array}$ & $\begin{array}{l}\text { The study was an update of EPF } \\
\text { techniques of Weron (2014), [108]. }\end{array}$ \\
\hline $\begin{array}{l}\text { Osorio et al. (2015), } \\
\text { [109]. }\end{array}$ & $\begin{array}{l}\text { Portuguese TSO } \\
\text { (REN)/2007-2008 }\end{array}$ & Portugal & $\begin{array}{c}\text { Hybrid } \\
\text { evolutionary-adaptive } \\
\text { method }\end{array}$ & $\begin{array}{l}\text { A new hybrid method was tested } \\
\text { and reduce the uncertainty of } \\
\text { wind power predictions. }\end{array}$ \\
\hline $\begin{array}{l}\text { Yang and Schell, } \\
\text { (2021), [103]. }\end{array}$ & $\begin{array}{l}\text { NYISO/ } \\
\text { historical data }\end{array}$ & US (New York) & Deep neural networks & $\begin{array}{c}\text { It was displayed that TL improved } \\
\text { accuracy across all } \\
\text { network representations. }\end{array}$ \\
\hline $\begin{array}{l}\text { Yang and Schell, } \\
\text { (2022), [105]. }\end{array}$ & $\begin{array}{l}\text { NYISO/ } \\
\text { historical data }\end{array}$ & US (New York) & Deep learning model & $\begin{array}{c}\text { The deep learning model was } \\
\text { developed and it was shown that } \\
\text { it performed well on time series } \\
\text { for EPF. }\end{array}$ \\
\hline $\begin{array}{l}\text { Zhang et al. (2012), } \\
\text { [110]. }\end{array}$ & NSW/2006 & Australia & $\begin{array}{l}\text { WT, ARIMA and } \\
\text { LSDVM }\end{array}$ & $\begin{array}{l}\text { It was shown that the preferred } \\
\text { method performed well on EPF. }\end{array}$ \\
\hline \multicolumn{3}{|c|}{$\begin{array}{l}\text { ARIMA: Autoregressive integrated moving average } \\
\text { CENACE: Natural Center for Energy Control } \\
\text { CONAGUA: Natural Water Commission } \\
\text { CRE: Energy Regulatory Commission } \\
\text { ENTSO-E: European Network of Transmission System Operators } \\
\text { for Electricity }\end{array}$} & $\begin{array}{l}\text { EPEX: The European } \\
\text { Power Exchange } \\
\text { LSSVM: Shrinkage and } \\
\text { selection operator least } \\
\text { squares support } \\
\text { vector machine }\end{array}$ & $\begin{array}{c}\text { NYISO: The New York } \\
\text { Independent System Operator } \\
\text { GEFCom: The Global Energy } \\
\text { Forecasting Competition } \\
\text { NSW: New South Wales } \\
\text { TSO: Transmission } \\
\text { system operator } \\
\text { WT: Wavelet transform }\end{array}$ \\
\hline
\end{tabular}

The need for artificial intelligence models comes from the non-linear characteristics of electricity price. Since the large number of time series models have linear predictors, the time series techniques lack the ability to capture the behavior of the price signal [64]. Neural [47] and fuzzy neural networks [111] are proposed due to solving this problem. Nonetheless, due to functional relationship of electricity price with time and the nature (characteristics) of electricity price, it is a time variant signal; therefore, neural and fuzzy neural network solutions may not be sufficient for precise forecasting results [64], and it needs hybrid models, which are the combination of non-linear and linear modelling capabilities occurs.

Hybrid models have a very complex forecasting structure, including several algorithms for decomposing or cluster data, feature selection, combined forecasting models, and heuristic optimization [112]. The most commonly preferred decomposition method is the wavelet transform [113-122]. Other decomposition studies that used empirical mode are given in [123-129]. The most widely preferred feature selection methods are the correlation analysis are presented in [118,123,130-132], and the mutual information method in $[121,123,130,133-135]$. The algorithms for the clustering data are based on: (1) k-means [136,137]; (2) enhanced game [136]; (3) self-organizing maps [114,136,138]; and (4) fuzzy [121,139]. Combined forecasting models for hybrid models that build on more than one method are very common. Some examples can be found in $[114,116,124,135,140,141]$. The heuristic optimization studies can be found in $[126,131,133,139]$. The major problems in employing hybrid model are [112]: (1) The proposed methods avoid to be compared with well-build models; (2) the used data sets are small; (3) lack of analysis of the effect of selecting different components.

Various middle/long term models on electricity market price and load forecasting through wind energy examples are shown in Table 5. These models can be gathered by time series analysis. Specifically, a case study for US (Texas) [142], the sensitivity analysis through scenarios for Australia [143], balancing the cost of electricity demand 
with large amount of wind energy for Australia [144], data analysis techniques through electricity demand models for Australia [145], WILMAR model through scenarios for Ireland and Great Britain [146]. Monte Carlo simulations for Mykonos (Greece) and La Ventosa (Mexico) [147], and for Denmark [148]. Simulations with stochastic and robust optimization for China [149], a market equilibrium model for China [150]. A modelling demand response utility function for Iran [151], and a dispatch model for Colombia [152] can be given as country specific examples.

Table 5. A literature review through middle/long term models on electricity market price and load forecasting through wind energy.

\begin{tabular}{|c|c|c|c|c|}
\hline Author (s) & Data/Period & Country & Method (s) & Findings \\
\hline $\begin{array}{l}\text { Baldick (2012), } \\
\text { [142]. }\end{array}$ & ERCOT empirical data & US & Case study for Texas & $\begin{array}{l}\text { Cost predictions are developed for } \\
\text { using wind energy to mitigate } \\
\qquad \mathrm{CO}_{2} \text { emissions. }\end{array}$ \\
\hline $\begin{array}{l}\text { Banaei et al. } \\
(2021),[4]\end{array}$ & Game theory data & - & $\begin{array}{l}\text { The supply function } \\
\text { model } \\
\text { (pricing models) }\end{array}$ & $\begin{array}{l}\text { Results showed that the applied } \\
\text { method reduced the market } \\
\text { players profit that depended } \\
\text { on uncertainties. }\end{array}$ \\
\hline $\begin{array}{l}\text { Bell et al. (2017), } \\
\text { [143]. }\end{array}$ & WRF data/2015 & Australia & $\begin{array}{l}\text { The sensitivity analysis } \\
\text { through scenarios }\end{array}$ & $\begin{array}{l}\text { The average wholesale spot price } \\
\text { in the NEM decreased due to the } \\
\text { increase in wind } \\
\text { power generation. }\end{array}$ \\
\hline $\begin{array}{l}\text { Blakers et al. } \\
(2021),[144] .\end{array}$ & NEM/2006-2010 & Australia & $\begin{array}{l}\text { Balancing the cost of } \\
\text { electricity demand with } \\
\text { high levels of } \\
\text { wind energy }\end{array}$ & $\begin{array}{l}\text { It is found that wind energy } \\
\text { generation led deployment on the } \\
\text { MCP, but it was modest. }\end{array}$ \\
\hline $\begin{array}{l}\text { Cutler et al. } \\
\text { (2011), [145]. }\end{array}$ & AEOM/2008-2010 & Australia & $\begin{array}{l}\text { Various data analysis } \\
\text { techniques through } \\
\text { electricity demand } \\
\text { models }\end{array}$ & $\begin{array}{l}\text { Wind power generation became a } \\
\text { significant secondary influence } \\
\text { (the relationship is inverse with } \\
\text { spot prices) after electricity } \\
\text { demand on spot prices. }\end{array}$ \\
\hline $\begin{array}{l}\text { Denny et al. } \\
(2010), \text { [146]. }\end{array}$ & AIGS & $\begin{array}{l}\text { Ireland and Great } \\
\text { Britain }\end{array}$ & $\begin{array}{l}\text { WILMAR model } \\
\text { through scenarios }\end{array}$ & $\begin{array}{l}\text { It was found that the increased } \\
\text { interconnection reduced both } \\
\text { average prices and the volatility of } \\
\text { those prices in countries. }\end{array}$ \\
\hline $\begin{array}{l}\text { Elfarra and Kaya } \\
\text { (2021), [147]. }\end{array}$ & $\begin{array}{l}\text { Akdağ et al. (2010), } \\
\text { [153]/2008-2009 }\end{array}$ & $\begin{array}{l}\text { Mykonos (Greece) } \\
\text { and La Ventosa } \\
\text { (Mexico) }\end{array}$ & $\begin{array}{l}\text { Annual energy } \\
\text { production through } \\
\text { Monte Carlo } \\
\text { simulations }\end{array}$ & $\begin{array}{l}\text { The PDFs (i.e., spline based) } \\
\text { produced minimum fitting error }\end{array}$ \\
\hline $\begin{array}{c}\text { Ji et al. } \\
\text { (2021), [149]. }\end{array}$ & $\begin{array}{l}\text { Simulation forecast } \\
\text { data }\end{array}$ & China & $\begin{array}{c}\text { Simulations with } \\
\text { stochastic and robust } \\
\text { optimization }\end{array}$ & $\begin{array}{l}\text { The validity and superiority of the } \\
\text { recommended models were } \\
\text { shown in case studies. }\end{array}$ \\
\hline $\begin{array}{l}\text { Khosravi et al. } \\
\text { (2022), [148]. }\end{array}$ & $\begin{array}{l}\text { WF power generation } \\
\text { and West Denmark } \\
\text { electricity markets }\end{array}$ & Denmark & $\begin{array}{l}\text { Stochastic scheduling, } \\
\text { simulations with } \\
\text { Monte-Carlo method }\end{array}$ & $\begin{array}{l}\text { Increase in the profit was observed } \\
\text { from the wind power } \\
\text { management method. }\end{array}$ \\
\hline $\begin{array}{l}\text { Liu and } \mathrm{Xu} \\
(2021),[150]\end{array}$ & CMDC/2013 & China & $\begin{array}{l}\text { A market } \\
\text { equilibrium model }\end{array}$ & $\begin{array}{l}\text { The impact of wind power } \\
\text { development on the spot market } \\
\text { price results were explored for } \\
\text { both long and short terms. }\end{array}$ \\
\hline $\begin{array}{l}\text { Niromandfam } \\
\text { et al. (2020), [151]. }\end{array}$ & $\begin{array}{l}\text { Ordoudis et al. } \\
\text { (2016), [154]. }\end{array}$ & Iran & $\begin{array}{l}\text { Modelling demand } \\
\text { response utility } \\
\text { function }\end{array}$ & $\begin{array}{l}\text { It was shown that the proposed } \\
\text { demand response utility function } \\
\text { improved the wind generation } \\
\text { profit in the DAM. }\end{array}$ \\
\hline
\end{tabular}


Table 5. Cont

\begin{tabular}{|c|c|c|c|c|}
\hline Author (s) & Data/Period & Country & Method (s) & Findings \\
\hline $\begin{array}{l}\text { Perez and } \\
\text { Garcia-Rendon, } \\
\text { (2021), [152]. }\end{array}$ & $\begin{array}{l}\text { Provided by the } \\
\text { authors through the } \\
\text { XM data/2018-2019 }\end{array}$ & Colombia & Dispatch model & $\begin{array}{l}\text { New bid prices in the market were } \\
\text { determined by the firms through } \\
\text { the structural model. }\end{array}$ \\
\hline \multicolumn{3}{|c|}{$\begin{array}{l}\text { AEMO: Australia Energy Market Operator } \\
\text { AIGS: All Island Grid Study } \\
\text { IDC: The China Meteorological Data Service Center } \\
\text { DAM: Day-ahead market } \\
\text { ERCOT: The electric reliability council of Texas }\end{array}$} & $\begin{array}{c}\text { MCP: Market } \\
\text { clearing price } \\
\text { NEM: The Australian } \\
\text { National Electricity } \\
\text { Market } \\
\text { PDFs: Probability } \\
\text { density functions }\end{array}$ & $\begin{array}{l}\text { WILMAR: A stochastic unit } \\
\quad \text { commitment model } \\
\text { WRF: Mesoscale numerical } \\
\text { weather prediction system }\end{array}$ \\
\hline
\end{tabular}

The long/middle term models include simulations (i.e., Monte Carlo simulations), market equilibrium models, production cost models, and fundamental models such as game theoretical approaches. The duration is longer or at least the considered period is middle-term in these models. They have remarkable theoretical contributions to the development of the EPF models by using economics terminology and approaches. Table 6 gives the main pros and cons of the reviewed methods and techniques based on the references that are given with Tables 2-5. Additionally, the last row of Table 6 shows the error comparison of the models that are selected among Tables 2-5.

Table 6. Main pros and cons of the reviewed methods based on the references in Tables 2-5.

\begin{tabular}{|c|c|c|c|c|}
\hline $\begin{array}{l}\text { Pros and Cons of the } \\
\text { Reviewed Methods }\end{array}$ & $\begin{array}{l}\text { Statistical Models } \\
\text { (First-Part) }\end{array}$ & $\begin{array}{l}\text { Statistical Models } \\
\text { (Second-Part) }\end{array}$ & $\begin{array}{l}\text { Artificial Intelligence and } \\
\text { Hybrid/Ensemble Models }\end{array}$ & $\begin{array}{l}\text { Middle/Long } \\
\text { Term Models }\end{array}$ \\
\hline Prons-1 & $\begin{array}{l}\text { Models allows the use of } \\
\text { data by converting them } \\
\text { from hourly to daily, } \\
\text { which reduce unwanted } \\
\text { and excessive noise. Their } \\
\text { implementtion are easy. }\end{array}$ & $\begin{array}{c}\text { Conditional } \\
\text { heteroscedasticity models } \\
\text { truly explain the } \\
\text { volatilities in prices (i.e., } \\
\text { seasonality, mean } \\
\text { reversion, and jumps). } \\
\text { Dynamic effects can } \\
\text { be considered. }\end{array}$ & $\begin{array}{l}\text { These models display } \\
\text { improved forcasting } \\
\text { performance in terms of } \\
\text { consistency, accuracy, and } \\
\text { statistical tests). } \\
\text { High-frequency electricity } \\
\text { price data forecasts } \\
\text { are possible. }\end{array}$ & $\begin{array}{l}\text { More realistic modes can } \\
\text { be possible to visualize the } \\
\text { market players' } \\
\text { behaviours (i.e., risk } \\
\text { management preferences). }\end{array}$ \\
\hline Prons-2 & $\begin{array}{l}\text { Model allows omitting } \\
\text { variables which their } \\
\text { inclusion in regressions } \\
\text { may generate an } \\
\text { endogeneity problem. } \\
\text { They are wide-spread } \\
\text { preferred models. }\end{array}$ & $\begin{array}{l}\text { The negative electricity } \\
\text { prices can be included into } \\
\text { the models, which helps to } \\
\text { conduct analysis without } \\
\text { shifting or cutting off } \\
\text { the series. }\end{array}$ & $\begin{array}{l}\text { Private information and } \\
\text { imperfect market structure } \\
\text { (i.e., oligopolies) can be } \\
\text { included and represented with } \\
\text { these models. }\end{array}$ & $\begin{array}{l}\text { Theorethical economic } \\
\text { models (i.e., Nash } \\
\text { Equilibrium conditions) } \\
\text { can be implemented } \\
\text { with simulations. }\end{array}$ \\
\hline Prons-3 & $\begin{array}{l}\text { Models allows to control } \\
\text { the seasonal effects by } \\
\text { introducing time } \\
\text { dummies. }\end{array}$ & $\begin{array}{l}\text { The causality tests can be } \\
\text { implemented in the } \\
\text { context of multivariate } \\
\text { during off-peak hours, } \\
\text { peak hours, and all hours. }\end{array}$ & $\begin{array}{c}\text { These methods are capable of } \\
\text { learning lon-term } \\
\text { dependencies. They cen } \\
\text { control how information is } \\
\text { abandoned or memorized } \\
\text { throughout time. }\end{array}$ & $\begin{array}{l}\text { Strategical behaviours of } \\
\text { the market participants } \\
\text { can be modeled } \\
\text { and simulated. }\end{array}$ \\
\hline Prons-4 & $\begin{array}{l}\text { Binary variables for the } \\
\text { weekend can be included } \\
\text { in models. }\end{array}$ & $\begin{array}{l}\text { More accurate estimations } \\
\text { of load and wind with } \\
\text { these models might } \\
\text { improve EPF. }\end{array}$ & $\begin{array}{l}\text { These models are reliable and } \\
\text { robust for the system's } \\
\text { complexity. Specifically, the } \\
\text { ensemble methods have better } \\
\text { results than their } \\
\text { individual equivalents. }\end{array}$ & $\begin{array}{l}\text { Parametric and } \\
\text { nonparamatric methods } \\
\text { can be } \\
\text { simultaneously } \\
\text { implemented. }\end{array}$ \\
\hline Prons-5 & $\begin{array}{l}\text { Yearly, monthly, daily, and } \\
\text { hourly dummies can be } \\
\text { used to control for } \\
\text { systematic } \\
\text { demand changes. }\end{array}$ & $\begin{array}{l}\text { These models (i.e., ARX) } \\
\text { can utilize both the } \\
\text { information on system } \\
\text { forecasts and actual past } \\
\text { realizations of } \\
\text { these variables. }\end{array}$ & $\begin{array}{l}\text { Decision-making strategies } \\
\text { can be done with these model } \\
\text { and these models can be } \\
\text { implemented for other regions } \\
\text { to improve EPF efficiency. }\end{array}$ & $\begin{array}{l}\text { Seasonal effects can be } \\
\text { simulated effectively. }\end{array}$ \\
\hline
\end{tabular}


Table 6. Cont.

\begin{tabular}{|c|c|c|c|c|}
\hline $\begin{array}{l}\text { Pros and Cons of the } \\
\text { Reviewed Methods }\end{array}$ & $\begin{array}{c}\text { Statistical Models } \\
\text { (First-Part) }\end{array}$ & $\begin{array}{l}\text { Statistical Models } \\
\text { (Second-Part) }\end{array}$ & $\begin{array}{l}\text { Artificial Intelligence and } \\
\text { Hybrid/Ensemble Models }\end{array}$ & $\begin{array}{l}\text { Middle/Long } \\
\text { Term Models }\end{array}$ \\
\hline Cons-1 & $\begin{array}{l}\text { There can be a lack of } \\
\text { certainity on estimations } \\
\text { of net effects for } \\
\text { individual consumers. } \\
\text { Estimated prices can be } \\
\text { different (i.e., higher) than } \\
\text { observed spot } \\
\text { market prices. }\end{array}$ & $\begin{array}{l}\text { The stochastic nature of } \\
\text { weather conditions causes } \\
\text { the volatilities of wind } \\
\text { power. This effects } \\
\text { electiricity prices } \\
\text { electricity price } \\
\text { spikes occur. }\end{array}$ & $\begin{array}{l}\text { The decion-making rules are } \\
\text { difficult to validate. The } \\
\text { implementations might be } \\
\text { time-consuming. }\end{array}$ & $\begin{array}{l}\text { The models might be case } \\
\text { dependent and different } \\
\text { findings can be obtained } \\
\text { for other situtaitions. }\end{array}$ \\
\hline Cons-2 & $\begin{array}{l}\text { The differences in wind } \\
\text { load profiles can affect the } \\
\text { hours of the day and } \\
\text { electricity prices can be } \\
\text { dependent on } \\
\text { these changes. }\end{array}$ & $\begin{array}{l}\text { Mean absolute errors } \\
\text { might not work properly } \\
\text { when the models with } \\
\text { more variables } \\
\text { are considered. }\end{array}$ & $\begin{array}{l}\text { These methods have a } \\
\text { significantly increased } \\
\text { computational burden. }\end{array}$ & $\begin{array}{l}\text { Prediction of wind power } \\
\text { effect on prices is difficult } \\
\text { due to the wide range of } \\
\text { factors (i.e., uncertain } \\
\text { demand, several } \\
\text { contingencies depend on } \\
\text { long-term forecasting } \\
\text { intervals). }\end{array}$ \\
\hline Cons-3 & $\begin{array}{l}\text { Many of the variables tend } \\
\text { to show near-unit root, or } \\
\text { autoregrsssive properties; } \\
\text { therefore, lags of the } \\
\text { variables should be } \\
\text { included into the models. }\end{array}$ & $\begin{array}{l}\text { The system of equations } \\
\text { need many parameters } \\
\text { and the estimation of the } \\
\text { coefficients are reletively } \\
\text { difficult or complex. }\end{array}$ & $\begin{array}{l}\text { Irrelevent asssumtions might } \\
\text { block or decrease the } \\
\text { performance of the estimator. }\end{array}$ & $\begin{array}{l}\text { If the computation time } \\
\text { increases with problem } \\
\text { size, this might weaken } \\
\text { the solution capabilitiy of } \\
\text { the concentrated problem. }\end{array}$ \\
\hline Cons-4 & $\begin{array}{l}\text { Possible endogeneity } \\
\text { problems cause from } \\
\text { either omitted variables or } \\
\text { reverse causalities (i.e., the } \\
\text { aggregate or average } \\
\text { electricity demand). }\end{array}$ & $\begin{array}{l}\text { ARMA type models are } \\
\text { bounded by the } \\
\text { assumption of constant } \\
\text { variance that yields } \\
\text { inconsistancy through } \\
\text { volatility. }\end{array}$ & $\begin{array}{l}\text { Various open-source software } \\
\text { platforms might be needed, so } \\
\text { that any researchers can } \\
\text { implement the codes as } \\
\text { benchmarks in their } \\
\text { individual studies. }\end{array}$ & \\
\hline $\begin{array}{l}\text { Error comparison of } \\
\text { the models }\end{array}$ & - & $\begin{array}{c}\text { Lasso (Ziel, 2016) [85], } \\
\text { MAAPE (\%): 6.604, RMSE: } \\
\text { 2.715, MAE: } 1.819\end{array}$ & $\begin{array}{c}\text { Ensemble learning model } \\
\text { (Bhatia, 2021) [101], MAAPE } \\
\text { (\%): 5.132, RMSE: } 2.156, \\
\text { MAE: } 1.385\end{array}$ & - \\
\hline
\end{tabular}

Note: The last row of Table 6 shows the comparison of the Lasso and Ensemble learning models in terms of mean arctangent absolute percentage error (MAAPE), mean absolute error (MAE), and root mean squared error (RMSE).

\section{Discussion of Forecasting Models on Electricity Markets}

Electricity price and load are determined by day-ahead, intra-day, and balancing markets all around the world; however, research shows that, although its data are usually publicly available, market clearing price forecasting is more complex (i.e., fuel prices; equipment outages; and the nature of the market clearing price depends on the hourly loads creates this complexity [155]) than the load price forecasting.

Forecasting the electricity market's prices is needed as a result of the dynamic features of markets, moving from deregulated to regulated form, that cause price volatility. Thereby, well performed MCP estimation and its confidence interval prediction may help power producers and its utilities when submitting bids in cases that are more risk-free (i.e., they can adjust their producers' supply and profits) [155]. Moreover, with reliable daily price forecasting, energy service companies or producers are able to lay out better financial contracts or bilateral ones. The complexity of forecasting electricity markets price and load is also dependent on the increasing number of employed variables as input for better accuracy $[64,112]$. Thereby, the trend in methodologies moves to more sophisticated instruments, such as hybrid models, as shown and discussed in this review.

In addition to the explanation of operating principles of the electricity market, it is understood from the papers examined in this review that renewable energy resources should be preferred, transforming the structure of electricity markets for better environment conditions with low-carbon levels. Incentives and supply security can be the instruments for all countries [156].

Many methods and models have been developed for the EPF of markets for the last two decades. As a result of the stochastic and nonlinear nature of statistical models and price series, autoregression, moving average, exponential smoothing, and their variants [33,157] have shown to be insufficient [49]. The artificial intelligence models are able to capture non-linearity and complexities and flexible [47,158-160]. 
Artificial neural networks are outstanding for short-term forecasting, and they are efficiently applicable for electricity markets [161], being more accurate and robust than autoregressive (AR) models. The research [48] uses artificial neural network models to display the strong impact of electricity price on the trend load and MCP. Singhal and Swarup [48] apply artificial neural network models to study the dependency of electricity price in MCP and electricity load. Wang et al. [159] implement a deep neural network model to forecast the price in US electricity markets, differently from conventional models of neural networks. This model supports vector regression. On the other hand, since the price series are volatile, the neural network models have potential to lose the properties of the value of prices [64]. Moreover, neural networks are not convenient for too short-term predictions, since they need high training time. As a result of the aforementioned issues, artificial intelligence models have handicaps in perfect price forecasting [108].

Relying on a sole forecasting electricity price model may fail in the treatment of network features in the short term. In those circumstances, hybrid models can be a better alternative for price forecasting. An example of a hybrid model which is a composition of a stochastic approach with a neural network model is given in [135]. Ghayekhloo et al. [136] show hybrid models that include game theoretic approaches. Signal decomposition methods are also used in hybrid models such as empirical mode decomposition and wavelet transform; the examples are given in $[115,162,163]$. Although the performance is significantly improved by those models, the computational cost can be disadvantageous [101].

\section{Conclusions}

The power industry is rapidly growing all over the world, and renewable energy resources are one of the most vital components in electricity production. Besides, renewable energy has environmentally friendly features (i.e., a considerable reduction of emission helps to mitigate global warming). To this end, increasing wind energy utilization is a challenge to provide electricity power for electricity markets. For the last two decades, the electricity market mechanisms have been faced with regulation procedures designed by decision and policy-making processes. The competition is the key factor to decreasing the cost of electricity and reliably meeting-demand solutions. However, the price spikes and price volatilities, due to various environmental and business factors, are the handicaps of this commodity. These handicaps encourage researchers to produce more effective instruments, techniques, and solutions.

This review paper gathers the latest electricity price and load forecasting techniques and discusses their strengths and weaknesses. Nevertheless, electricity trading markets are becoming more sophisticated, with novel types of contracts in the bilateral transactions or organized markets due to an existing free market competition rule. The independent transmission system operators for each specific market have the responsibility of controlling the entire transmission networks. The price mechanism operates with market clearing price, which is obtained by the law of supply and demand curves that are determined in the day-ahead markets. The price deviations caused by supply and demand forces are corrected in balancing power markets by transmission system operators. Moreover, the intra-day markets are functioning as a bridge between the day-ahead markets and balancing markets. Market participants, who do not sell their entire power or do not take their positions in the day-ahead markets, have the alternative to sell or buy the needed power in the intra-day markets.

As a methodology, this review paper follows the historical and structural development of electricity markets, price and load forecasting methods, and recent trends in wind energy generation, transmission, and consumption. The findings that are based on the considered studies in this review reveal that:

The merit order effect is found for wind power generation, which means that wind power decreases wholesale price of electricity, however, it increases its volatility.

The volatility of wind power is induced by the stochastic character of weather conditions; therefore, both the parametric and non-parametric techniques might be needed in 
the calculations. Moreover, this indirectly effects the market clearing prices; however, the volatility of electricity prices is driven by the market design.

Technically, the models can be calibrated by transforming data, known as variance stabilizing transformation, which yields more accurate predictions along with less spikes and lower variation features of data.

As the EPF and load methods tend to be explained more dimensionally (i.e., hybrid methods including deep learning and artificial intelligence), the performance of the methods increase in terms of accuracy, stability, and consistency. Besides, both the linear and the non-linear nature of electricity price data can be observed in this way.

The regulatory interventions due to Covid-19 pandemic and the carbon pricing mechanism might have an adverse effect on electricity price dynamics. However, inventions of new vaccines and pills and prevalent use of renewable energy sources (i.e., wind and solar energy) will lessen the unpredicted effects of Covid-19 and carbon emissions.

Nevertheless, extreme weather events that are related with climate change seem a barrier for electricity market participants through wind energy production in the near future. Therefore, future studies may consider those facts and propose new forecasting techniques and improvements for better market operations. As a practical solution proposal, a cooperation between government, energy producers, manufacturers, and researchers in developing countries might lead to the start of arrangements whereby produced power can be directly delivered to energy-intensive factories, such as fertilizer factories (i.e., fertilizer industry require significant electricity in the world). Therefore, energy transfer losses can be prevented and, with special agreements, the manufacturers can benefit from these arrangements as a means of production cost reduction and wind farm owners can benefit from the utilization of produced electricity without any restriction. As a theoretical solution proposal, research has demonstrated that a large installed capacity of wind energy might reduce wind power variability. Thereby, smooth wind generation could be possible by utilizing storage optimization systems and flexible electricity interconnections (i.e., high voltage direct current systems with voltage source converters operating for wind farms).

Author Contributions: Study conception and design: H.A. and F.P.G.M.; acquisition, analysis, drawing figures, and interpretation of data: H.A. and F.P.G.M.; drafting of manuscript: H.A. and F.P.G.M.; critical revision: H.A. and F.P.G.M. All authors have read and agreed to the published version of the manuscript.

Funding: This research received no external funding.

Institutional Review Board Statement: Not applicable.

Informed Consent Statement: Not applicable.

Data Availability Statement: Not applicable.

Acknowledgments: The work reported herewith has been financially by the Dirección General de Universidades, Investigación e Innovación of Castilla-La Mancha, under Research Grant ProSeaWind project (Ref.: SBPLY/19/180501/000102). We are grateful to three anonymous reviewers that helped us to improve the paper.

Conflicts of Interest: The authors declare no conflict of interest. 


\section{Nomenclature}

\begin{tabular}{|c|c|}
\hline AEMO & Australia Energy Market Operator \\
\hline AIGS & All Island Grid Study \\
\hline APX & Amsterdam Power Exchange \\
\hline AR & Autoregression \\
\hline ARDL & Autoregressive distributed lag \\
\hline ARMAX & Autoregressive moving average model with exogenous regressors \\
\hline ARX & Auto-regressive with eXternal model input \\
\hline Belpex & Belgian Power Exchange \\
\hline BPM & Balancing power market \\
\hline CalPX & California Power Exchange \\
\hline CMDC & The China Meteorological Data Service Center \\
\hline CRE & Energy Regulatory Commission \\
\hline DAM & Day-ahead market \\
\hline EEX & European Energy Exchange \\
\hline eGARCH & Exponential generalized autoregressive conditional heteroskedasticity \\
\hline ENTSO-E & European Network of Transmission System Operators for Electricity \\
\hline EPFs & Electricity price forecasts \\
\hline EEX & European Energy Exchange \\
\hline EPEX & European Power Exchange \\
\hline EPIAS & Energy Exchange Istanbul \\
\hline ERCOT & The electric reliability council of Texas \\
\hline EXAA & Energy Exchange Austria \\
\hline GARCH & Generalized autoregressive conditional heteroskedasticity \\
\hline GEFCom & Global Energy Forecasting Competition \\
\hline GME & Gestore dei Mercati Energetici \\
\hline IDM & Intra-day market \\
\hline IPEX & Italian Power Exchange \\
\hline LASSO & Least absolute shrinkage and selection operator \\
\hline LPX & Leipzig Power Exchange \\
\hline LSSVM & Shrinkage and selection operator least squares support vector machine \\
\hline MCP & Market clearing price \\
\hline MISO & Midwest ISO \\
\hline NYISO & New York ISO \\
\hline NEM & Australian National Electricity Market \\
\hline NSW & New South Wales \\
\hline NYISO & New York Independent System Operator \\
\hline OLS & Ordinary least squares \\
\hline OMEL & Operadora del mercado espanol de electricidad \\
\hline PJM & Pennsylvania-New Jersey Maryland Interconnection \\
\hline PolPX & Polish Power Exchange \\
\hline QRM & Quantile Regression Machine \\
\hline SCAR & Seasonal component autoregressive \\
\hline TSO & Transmission system operator \\
\hline UKPX & UK Power Exchange \\
\hline VAR & Vector autoregressive \\
\hline WILMAR & A stochastic unit commitment model \\
\hline WRF & Mesoscale numerical weather prediction system \\
\hline
\end{tabular}

\section{References}

1. Weron, R. Modeling and Forecasting Electricity Loads and Prices: A Statistical Approach; Wiley Finance Series; John Wiley \& Sons: Chichester, UK, 2006.

2. Kaminski, V. Energy Markets/Vincent Kaminski; Risk Books: London, UK, 2012.

3. Mohammad, S.; Hatim, Y.; Zuyi, L. Market Operations in Electric Power Systems: Forecasting, Scheduling, and Risk Management; John Wiley \& Sons: Hoboken, NJ, USA, 2002.

4. Banaei, M.; Raouf-Sheybani, H.; Oloomi-Buygi, M.; Boudjadar, J. Impacts of large-scale penetration of wind power on day-ahead electricity markets and forward contracts. Int. J. Electr. Power Energy Syst. 2021, 125, 106450. [CrossRef] 
5. Márquez, F.P.G.; Karyotakis, A.; Papaelias, M. Renewable Energies: Business Outlook 2050; Springer: Berlin, Germany, 2018.

6. Salam, R.A.; Amber, K.P.; Ratyal, N.I.; Alam, M.; Akram, N.; Muñoz, C.Q.G.; Márquez, F.P.G. An Overview on Energy and Development of Energy Integration in Major South Asian Countries: The Building Sector. Energies 2020, 13, 5776. [CrossRef]

7. Dey, B.; Márquez, F.P.G.; Basak, S.K. Smart Energy Management of Residential Microgrid System by a Novel Hybrid MGWOSCACSA Algorithm. Energies 2020, 13, 3500. [CrossRef]

8. Dey, B.; Raj, S.; Mahapatra, S.; Márquez, F.P.G. Optimal scheduling of distributed energy resources in microgrid systems based on electricity market pricing strategies by a novel hybrid optimization technique. Int. J. Electr. Power Energy Syst. 2022, 134, 107419. [CrossRef]

9. Bunn, D.W. Modelling Prices in Competitive Electricity Markets; Wiley Finance Series; John Wiley \& Sons: London, UK, 2004.

10. Eydeland, A.; Wolyniec, K. Energy and Power Risk Management: New Developments in Modeling, Pricing, and Hedging; John Wiley \& Sons: Hoboken, NJ, USA, 2003.

11. Singh, S.; Fozdar, M.; Malik, H.; Fernández Moreno, M.D.V.; García Márquez, F.P. Influence of Wind Power on Modeling of Bidding Strategy in a Promising Power Market with a Modified Gravitational Search Algo-rithm. Appl. Sci. 2021, 11, 4438. [CrossRef]

12. Golmohamadi, H.; Asadi, A. A multi-stage stochastic energy management of responsive irrigation pumps in dynamic electricity markets. Appl. Energy 2020, 265, 114804. [CrossRef]

13. Qian, Z.; Pei, Y.; Zareipour, H.; Chen, N. A review and discussion of decomposition-based hybrid models for wind energy forecasting applications. Appl. Energy 2019, 235, 939-953. [CrossRef]

14. Albadi, M.; El-Saadany, E. A summary of demand response in electricity markets. Electr. Power Syst. Res. 2008, 78, 1989-1996. [CrossRef]

15. Soloviova, M.; Vargiolu, T. Efficient representation of supply and demand curves on day-ahead electricity markets. J. Energy Mark. 2021, 14. [CrossRef]

16. Oskouei, M.Z.; Mirzaei, M.A.; Mohammadi-Ivatloo, B.; Shafiee, M.; Marzband, M.; Anvari-Moghaddam, A. A hybrid robuststochastic approach to evaluate the profit of a multi-energy retailer in tri-layer energy markets. Energy 2021, $214,118948$. [CrossRef]

17. Grimm, V.; Rückel, B.; Sölch, C.; Zöttl, G. The impact of market design on transmission and generation investment in electricity markets. Energy Econ. 2021, 93, 104934. [CrossRef]

18. Elsisi, M.; Bazmohammadi, N.; Guerrero, J.M.; Ebrahim, M.A. Energy management of controllable loads in multi-area power systems with wind power penetration based on new supervisor fuzzy nonlinear sliding mode control. Energy 2021, $221,119867$. [CrossRef]

19. Basit, A.; Hansen, A.D.; Sørensen, P.E.; Giannopoulos, G. Real-time impact of power balancing on power system operation with large scale integration of wind power. J. Mod. Power Syst. Clean Energy 2015, 5, 202-210. [CrossRef]

20. Elsisi, M.; Soliman, M. Optimal design of robust resilient automatic voltage regulators. ISA Trans. 2021, 108, 257-268. [CrossRef]

21. Elsisi, M.; Soliman, M.; Aboelela, M.; Mansour, W. Improving the grid frequency by optimal design of model predictive control with energy storage devices. Optim. Control. Appl. Methods 2018, 39, 263-280. [CrossRef]

22. Elsisi, M. New variable structure control based on different meta-heuristics algorithms for frequency regulation considering nonlinearities effects. Int. Trans. Electr. Energy Syst. 2020, 30, 12428. [CrossRef]

23. Elsisi, M. New design of robust PID controller based on meta-heuristic algorithms for wind energy conversion system. Wind. Energy 2019, 23, 391-403. [CrossRef]

24. Lei, M.; Shiyan, L.; Chuanwen, J.; Hongling, L.; Yan, Z. A review on the forecasting of wind speed and generated power. Renew. Sustain. Energy Rev. 2009, 13, 915-920. [CrossRef]

25. Foley, A.M.; Leahy, P.G.; Marvuglia, A.; McKeogh, E.J. Current methods and advances in forecasting of wind power generation. Renew. Energy 2012, 37, 1-8. [CrossRef]

26. Al-Yahyai, S.; Charabi, Y.; Gastli, A. Review of the use of Numerical Weather Prediction (NWP) Models for wind energy assessment. Renew. Sustain. Energy Rev. 2010, 14, 3192-3198. [CrossRef]

27. Peter, Z.; Aaron, P.; Georg, E. Energy Economics: Theory and Applications (Springer Texts in Business and Economics); Springer: Berlin/Heidelberg, Germany, 2017. (In English)

28. Ocker, F.; Jaenisch, V. The way towards European electricity intraday auctions-Status quo and future developments. Energy Policy 2020, 145, 111731. [CrossRef]

29. Chaves-Ávila, J.P.; Fernandes, C. The Spanish intraday market design: A successful solution to balance renewable generation? Renew. Energy 2015, 74, 422-432. [CrossRef]

30. Maciejowska, K.; Nitka, W.; Weron, T. Enhancing load, wind and solar generation for day-ahead forecasting of electricity prices. Energy Econ. 2021, 99, 105273. [CrossRef]

31. Gianfreda, A.; Parisio, L.; Pelagatti, M.; Gianfreda, A.; Parisio, L.; Pelagatti, M. The Impact of RES in the Ital-ian Day-Ahead and Balancing Markets. Energy J. 2016, 37, 161-184. Available online: https://stanford.idm.oclc.org/login?url=https://search. ebscohost.com/login.aspx?direct=true\&site=eds-live\&db=edsjsr\&AN=edsjsr.26606234 (accessed on 1 October 2021).

32. Koch, C.; Hirth, L. Short-term electricity trading for system balancing: An empirical analysis of the role of intraday trading in balancing Germany's electricity system. Renew. Sustain. Energy Rev. 2019, 113, 109275. [CrossRef] 
33. Girish, G. Spot electricity price forecasting in Indian electricity market using autoregressive-GARCH models. Energy Strat. Rev. 2016, 11-12, 52-57. [CrossRef]

34. Day ahead Market Web Application, Used Guide. 2016. Available online: https://www.epias.com.tr/wp-content/uploads/2017 /09/ENG-DAM-User-Guide_vol_5.pdf (accessed on 27 September 2021).

35. EPİAŞ. Day-ahead Market. EPİAŞ. Available online: https://www.epias.com.tr/en/day-ahead-market/introduction/ (accessed on 27 September 2021).

36. Green, R. Electricity liberalisation in Europe-How competitive will it be? Energy Policy 2006, 34, 2532-2541. [CrossRef]

37. Moreno, B.; López, A.J.; García-Álvarez, M.T. The electricity prices in the European Union. The role of renewable energies and regulatory electric market reforms. Energy 2012, 48, 307-313. [CrossRef]

38. Weber, C. Adequate intraday market design to enable the integration of wind energy into the European power systems. Energy Policy 2010, 38, 3155-3163. [CrossRef]

39. EPİA̧. Intra-Day Market. EPİAŞ. Available online: https://www.epias.com.tr/en/intra-day-market/introduction/ (accessed on 27 September 2021).

40. Hagemann, S.; Weber, C. An Empirical Analysis of Liquidity and Its Determinants in the German Intraday Market for Electricity; EWL Working Paper No. 17/2013; University of Duisburg-Essen: Duisburg, Germany, 2013. [CrossRef]

41. Le, H.L.; Ilea, V.; Bovo, C. Integrated European intra-day electricity market: Rules, modeling and analysis. Appl. Energy 2019, 238, 258-273. [CrossRef]

42. Hu, X.; Jaraitè, J.; Kažukauskas, A. The effects of wind power on electricity markets: A case study of the Swedish intraday market. Energy Econ. 2021, 96, 105159. [CrossRef]

43. Dinler, A. Reducing balancing cost of a wind power plant by deep learning in market data: A case study for Turkey. Appl. Energy 2021, 289, 116728. [CrossRef]

44. Dey, B.; Bhattacharyya, B.; Márquez, F.P.G. A hybrid optimization-based approach to solve environment constrained economic dispatch problem on microgrid system. J. Clean. Prod. 2021, 307, 127196. [CrossRef]

45. EPİAŞ. Balancing Market. Available online: https://www.epias.com.tr/genel-esaslar/ (accessed on 27 September 2021).

46. Vandezande, L.; Meeus, L.; Belmans, R.; Saguan, M.; Glachant, J.-M. Well-functioning balancing markets: A prerequisite for wind power integration. Energy Policy 2010, 38, 3146-3154. [CrossRef]

47. Anbazhagan, S.; Kumarappan, N. Day-Ahead Deregulated Electricity Market Price Forecasting Using Recurrent Neural Network. IEEE Syst. J. 2012, 7, 866-872. [CrossRef]

48. Singhal, D.; Swarup, S. Electricity price forecasting using artificial neural networks. Int. J. Electr. Power Energy Syst. 2011, 33, 550-555. [CrossRef]

49. Chan, S.-C.; Tsui, K.M.; Wu, H.C.; Hou, Y.; Wu, Y.C.; Wu, F.F. Load/Price Forecasting and Managing Demand Response for Smart Grids: Methodologies and Challenges. IEEE Signal Process. Mag. 2012, 29, 68-85. [CrossRef]

50. Kalay, O. Electricity Load and Price Forecasting of Turkish Electricity Markets. Master's Thesis, Middle East Technical University, Ankara, Turkey, 2018.

51. Tashpulatov, S. Estimating the volatility of electricity prices: The case of the England and Wales wholesale electricity market. Energy Policy 2013, 60, 81-90. [CrossRef]

52. Hellström, J.; Lundgren, J.; Yu, H. Why do electricity prices jump? Empirical evidence from the Nordic electricity market. Energy Econ. 2012, 34, 1774-1781. [CrossRef]

53. Weron, R.; Zator, M. Revisiting the relationship between spot and futures prices in the Nord Pool electricity market. Energy Econ. 2014, 44, 178-190. [CrossRef]

54. Philpott, A.; Read, G.; Batstone, S.; Miller, A. The New Zealand Electricity Market: Challenges of a Renewable Energy System. IEEE Power Energy Mag. 2019, 17, 43-52. [CrossRef]

55. Karabiber, O.A.; Xydis, G. Electricity Price Forecasting in the Danish Day-Ahead Market Using the TBATS, ANN and ARIMA Methods. Energies 2019, 12, 928. [CrossRef]

56. Su, W. The Role of Customers in the U.S. Electricity Market: Past, Present and Future. Electr. J. 2014, 27, 112-125. [CrossRef]

57. Olsson, M.; Perninge, M.; Söder, L. Modeling real-time balancing power demands in wind power systems using stochastic differential equations. Electr. Power Syst. Res. 2010, 80, 966-974. [CrossRef]

58. Fan, S.; Chen, L. Short-Term Load Forecasting Based on an Adaptive Hybrid Method. IEEE Trans. Power Syst. 2006, 21, $392-401$. [CrossRef]

59. Ranaweera, D.K.; Karady, G.G.; Farmer, R.G. Economic impact analysis of load forecasting. IEEE Trans. Power Syst. 1997, 12, 1388-1392. [CrossRef]

60. Abu-El-Magd, M.A.; Sinha, N.K. Short-Term Load Demand Modeling and Forecasting: A Review. IEEE Trans. Syst. Man Cybern. 1982, 12, 370-382. [CrossRef]

61. Moghram, I.; Rahman, S. Analysis and evaluation of five short-term load forecasting techniques. IEEE Trans. Power Syst. 1989, 4, 1484-1491. [CrossRef]

62. Amjady, N. Short-Term Bus Load Forecasting of Power Systems by a New Hybrid Method. IEEE Trans. Power Syst. 2007, 22, 333-341. [CrossRef]

63. Yun, Z.; Quan, Z.; Caixin, S.; Shaolan, L.; Yuming, L.; Yang, S. RBF Neural Network and ANFIS-Based Short-Term Load Forecasting Approach in Real-Time Price Environment. IEEE Trans. Power Syst. 2008, 23, 853-858. [CrossRef] 
64. Cerjan, M.; Krzelj, I.; Vidak, M.; Delimar, M. A literature review with statistical analysis of electricity price forecasting methods. In Proceedings of the Eurocon 2013, Zagreb, Croatia, 1-4 July 2013; pp. 756-763.

65. Clò, S.; Cataldi, A.; Zoppoli, P. The merit-order effect in the Italian power market: The impact of solar and wind generation on national wholesale electricity prices. Energy Policy 2015, 77, 79-88. [CrossRef]

66. Woo, C.; Moore, J.; Schneiderman, B.; Ho, T.; Olson, A.; Alagappan, L.; Chawla, K.; Toyama, N.; Zarnikau, J. Merit-order effects of renewable energy and price divergence in California's day-ahead and real-time electricity markets. Energy Policy 2016, 92, 299-312. [CrossRef]

67. Cludius, J.; Forrest, S.; MacGill, I. Distributional effects of the Australian Renewable Energy Target (RET) through wholesale and retail electricity price impacts. Energy Policy 2014, 71, 40-51. [CrossRef]

68. Cludius, J.; Hermann, H.; Matthes, F.C.; Graichen, V. The merit order effect of wind and photovoltaic electricity generation in Germany 2008-2016: Estimation and distributional implications. Energy Econ. 2014, 44, 302-313. [CrossRef]

69. Csereklyei, Z.; Qu, S.; Ancev, T. The effect of wind and solar power generation on wholesale electricity prices in Australia. Energy Policy 2019, 131, 358-369. [CrossRef]

70. Forrest, S.; MacGill, I. Assessing the impact of wind generation on wholesale prices and generator dispatch in the Australian National Electricity Market. Energy Policy 2013, 59, 120-132. [CrossRef]

71. Maciejowska, K. Assessing the impact of renewable energy sources on the electricity price level and variability-A quantile regression approach. Energy Econ. 2020, 85, 104532. [CrossRef]

72. Westgaard, S.; Fleten, S.-E.; Negash, A.; Botterud, A.; Bogaard, K.; Verling, T.H. Performing price scenario analysis and stress testing using quantile regression: A case study of the Californian electricity market. Energy 2021, 214, 118796. [CrossRef]

73. Spodniak, P.; Ollikka, K.; Honkapuro, S. The impact of wind power and electricity demand on the relevance of different short-term electricity markets: The Nordic case. Appl. Energy 2021, 283, 116063. [CrossRef]

74. Ketterer, J.C. The impact of wind power generation on the electricity price in Germany. Energy Econ. 2014, 44, 270-280. [CrossRef]

75. Kyritsis, E.; Andersson, J.; Serletis, A. Electricity prices, large-scale renewable integration, and policy implications. Energy Policy 2017, 101, 550-560. [CrossRef]

76. Mwampashi, M.M.; Nikitopoulos, C.S.; Konstandatos, O.; Rai, A. Wind generation and the dynamics of electricity prices in Australia. Energy Econ. 2021, 103, 105547. [CrossRef]

77. Pape, C.; Hagemann, S.; Weber, C. Are fundamentals enough? Explaining price variations in the German day-ahead and intraday power market. Energy Econ. 2016, 54, 376-387. [CrossRef]

78. Maciejowska, K.; Nitka, W.; Weron, T. Day-Ahead vs. Intraday-Forecasting the Price Spread to Maximize Economic Benefits. Energies 2019, 12, 631. [CrossRef]

79. Nowotarski, J.; Raviv, E.; Trueck, S.; Weron, R. An empirical comparison of alternative schemes for combining electricity spot price forecasts. Energy Econ. 2014, 46, 395-412. [CrossRef]

80. Paraschiv, F.; Erni, D.; Pietsch, R. The impact of renewable energies on EEX day-ahead electricity prices. Energy Policy 2014, 73, 196-210. [CrossRef]

81. Marcjasz, G.; Serafin, T.; Weron, R. Selection of Calibration Windows for Day-Ahead Electricity Price Forecasting. Energies 2018, 11, 2364. [CrossRef]

82. Uniejewski, B.; Nowotarski, J.; Weron, R. Automated Variable Selection and Shrinkage for Day-Ahead Electricity Price Forecasting Energies 2016, 9, 621. [CrossRef]

83. Uniejewski, B.; Weron, R. Efficient Forecasting of Electricity Spot Prices with Expert and LASSO Models. Energies 2018, 11, 2039. [CrossRef]

84. Uniejewski, B.; Marcjasz, G.; Weron, R. Understanding intraday electricity markets: Variable selection and very short-term price forecasting using LASSO. Int. J. Forecast. 2019, 35, 1533-1547. [CrossRef]

85. Ziel, F. Forecasting Electricity Spot Prices Using Lasso: On Capturing the Autoregressive Intraday Structure. IEEE Trans. Power Syst. 2016, 31, 4977-4987. [CrossRef]

86. Uniejewski, B.; Marcjasz, G.; Weron, R. On the importance of the long-term seasonal component in day-ahead electricity price forecasting. Energy Econ. 2019, 79, 171-182. [CrossRef]

87. Ziel, F.; Weron, R. Day-ahead electricity price forecasting with high-dimensional structures: Univariate vs. multivariate modeling frameworks. Energy Econ. 2018, 70, 396-420. [CrossRef]

88. Gürtler, M.; Paulsen, T. The effect of wind and solar power forecasts on day-ahead and intraday electricity prices in Germany. Energy Econ. 2018, 75, 150-162. [CrossRef]

89. Serafin, T.; Uniejewski, B.; Weron, R. Averaging Predictive Distributions Across Calibration Windows for Day-Ahead Electricity Price Forecasting. Energies 2019, 12, 2561. [CrossRef]

90. Ziel, F.; Steinert, R. Probabilistic mid- and long-term electricity price forecasting. Renew. Sustain. Energy Rev. 2018, 94, 251-266. [CrossRef]

91. Hubicka, K.; Marcjasz, G.; Weron, R. A Note on Averaging Day-Ahead Electricity Price Forecasts Across Calibration Windows. IEEE Trans. Sustain. Energy 2019, 10, 321-323. [CrossRef]

92. Tibshirani, R. Regression Shrinkage and Selection Via the Lasso. J. R. Stat. Soc. Ser. B 1996, 58, 267-288. [CrossRef]

93. Raviv, E.; Bouwman, K.E.; van Dijk, D. Forecasting day-ahead electricity prices: Utilizing hourly prices. Energy Econ. 2015, 50, 227-239. [CrossRef] 
94. Nowotarski, J.; Weron, R. On the importance of the long-term seasonal component in day-ahead electricity price forecasting. Energy Econ. 2016, 57, 228-235. [CrossRef]

95. Swider, D.J.; Weber, C. Extended ARMA models for estimating price developments on day-ahead electricity markets. Electr. Power Syst. Res. 2007, 77, 583-593. [CrossRef]

96. Worthington, A.; Kay-Spratley, A.; Higgs, H. Transmission of prices and price volatility in Australian electricity spot markets: A multivariate GARCH analysis. Energy Econ. 2005, 27, 337-350. [CrossRef]

97. Higgs, H.; Lien, G.; Worthington, A.C. Australian evidence on the role of interregional flows, production capacity, and generation mix in wholesale electricity prices and price volatility. Econ. Anal. Policy 2015, 48, 172-181. [CrossRef]

98. Han, L.; Kordzakhia, N.; Trück, S. Volatility spillovers in Australian electricity markets. Energy Econ. 2020, 90, 104782. [CrossRef]

99. Nelson, D.B. Conditional Heteroskedasticity in Asset Returns: A New Approach. Econom. J. Econom. Soc. 1991, 59, 347. [CrossRef]

100. Bordignon, S.; Bunn, D.W.; Lisi, F.; Nan, F. Combining day-ahead forecasts for British electricity prices. Energy Econ. 2013, 35, 88-103. [CrossRef]

101. Bhatia, K.; Mittal, R.; Varanasi, J.; Tripathi, M. An ensemble approach for electricity price forecasting in markets with renewable energy resources. Util. Policy 2021, 70, 101185. [CrossRef]

102. Li, W.; Becker, D.M. Day-ahead electricity price prediction applying hybrid models of LSTM-based deep learning methods and feature selection algorithms under consideration of market coupling. Energy 2021, 237, 121543. [CrossRef]

103. Yang, H.; Schell, K.R. Real-time electricity price forecasting of wind farms with deep neural network transfer learning and hybrid datasets. Appl. Energy 2021, 299, 117242. [CrossRef]

104. May, E.C.; Bassam, A.; Ricalde, L.J.; Soberanis, M.E.; Oubram, O.; Tzuc, O.M.; Alanis, A.Y.; Livas-García, A. Global sensitivity analysis for a real-time electricity market forecast by a machine learning approach: A case study of Mexico. Int. J. Electr. Power Energy Syst. 2022, 135, 107505. [CrossRef]

105. Yang, H.; Schell, K.R. GHTnet: Tri-Branch deep learning network for real-time electricity price forecasting. Energy 2022, 238, 122052. [CrossRef]

106. Bublitz, A.; Keles, D.; Fichtner, W. An analysis of the decline of electricity spot prices in Europe: Who is to blame? Energy Policy 2017, 107, 323-336. [CrossRef]

107. Nowotarski, J.; Weron, R. Recent advances in electricity price forecasting: A review of probabilistic forecasting. Renew. Sustain. Energy Rev. 2018, 81, 1548-1568. [CrossRef]

108. Weron, R. Electricity price forecasting: A review of the state-of-the-art with a look into the future. Int. J. Forecast. 2014, 30, 1030-1081. [CrossRef]

109. Osório, G.; Matias, J.; Catalão, J.P.S. Short-term wind power forecasting using adaptive neuro-fuzzy inference system combined with evolutionary particle swarm optimization, wavelet transform and mutual information. Renew. Energy 2015, 75, 301-307. [CrossRef]

110. Zhang, J.; Tan, Z.; Yang, S. Day-ahead electricity price forecasting by a new hybrid method. Comput. Ind. Eng. 2012, 63, 695-701. [CrossRef]

111. Amjady, N. Day-Ahead Price Forecasting of Electricity Markets by a New Fuzzy Neural Network. IEEE Trans. Power Syst. 2006, 21, 887-896. [CrossRef]

112. Lago, J.; Marcjasz, G.; De Schutter, B.; Weron, R. Forecasting day-ahead electricity prices: A review of state-of-the-art algorithms, best practices and an open-access benchmark. Appl. Energy 2021, 293, 116983. [CrossRef]

113. Chang, Z.; Zhang, Y.; Chen, W. Electricity price prediction based on hybrid model of adam optimized LSTM neural network and wavelet transform. Energy 2019, 187, 115804. [CrossRef]

114. Nazar, M.S.; Fard, A.E.; Heidari, A.; Shafie-Khah, M.; Catalão, J.P. Hybrid model using three-stage algorithm for simultaneous load and price forecasting. Electr. Power Syst. Res. 2018, 165, 214-228. [CrossRef]

115. Yang, Z.; Ce, L.; Lian, L. Electricity price forecasting by a hybrid model, combining wavelet transform, ARMA and kernel-based extreme learning machine methods. Appl. Energy 2017, 190, 291-305. [CrossRef]

116. Olamaee, J.; Mohammadi, M.; Noruzi, A.; Hosseini, S.M.H. Day-ahead price forecasting based on hybrid prediction model. Complex. 2016, 21, 156-164. [CrossRef]

117. Singh, N.; Mohanty, S.R.; Shukla, R.D. Short term electricity price forecast based on environmentally adapted generalized neuron. Energy 2017, 125, 127-139. [CrossRef]

118. Bento, P.; Pombo, J.; Calado, M.D.R.; Mariano, S.J.P.S. A bat optimized neural network and wavelet transform approach for short-term price forecasting. Appl. Energy 2018, 210, 88-97. [CrossRef]

119. Peter, S.E.; Raglend, I.J. Sequential wavelet-ANN with embedded ANN-PSO hybrid electricity price forecasting model for Indian energy exchange. Neural Comput. Appl. 2016, 28, 2277-2292. [CrossRef]

120. Anamika; Peesapati, R.; Kumar, N. Electricity Price Forecasting and Classification Through Wavelet-Dynamic Weighted PSOFFNN Approach. IEEE Syst. J. 2018, 12, 3075-3084. [CrossRef]

121. Gao, W.; Sarlak, V.; Parsaei, M.R.; Ferdosi, M. Combination of fuzzy based on a meta-heuristic algorithm to predict electricity price in an electricity markets. Chem. Eng. Res. Des. 2018, 131, 333-345. [CrossRef]

122. Zhang, J.; Tan, Z.; Li, C. A Novel Hybrid Forecasting Method Using GRNN Combined With Wavelet Transform and a GARCH Model. Energy Sources Part B Econ. Plan. Policy 2015, 10, 418-426. [CrossRef] 
123. Hong, Y.-Y.; Liu, C.-Y.; Chen, S.-J.; Huang, W.-C.; Yu, T.-H. Short-term LMP forecasting using an artificial neural network incorporating empirical mode decomposition. Int. Trans. Electr. Energy Syst. 2015, 25, 1952-1964. [CrossRef]

124. Zhang, J.-L.; Zhang, Y.-J.; Li, D.-Z.; Tan, Z.-F.; Ji, J.-F. Forecasting day-ahead electricity prices using a new integrated model. Int. J. Electr. Power Energy Syst. 2019, 105, 541-548. [CrossRef]

125. Kurbatsky, V.G.; Sidorov, D.; Spiryaev, V.; Tomin, N. Forecasting nonstationary time series based on Hilbert-Huang transform and machine learning. Autom. Remote Control. 2014, 75, 922-934. [CrossRef]

126. Gobu, B.; Jaikumar, S.; Arulmozhi, N.; Kanimozhi, P. Two-Stage Machine Learning Framework for Simultaneous Forecasting of Price-Load in the Smart Grid. In Proceedings of the 2018 17th IEEE International Conference on Machine Learning and Applications (ICMLA), Orlando, FL, USA, 17-20 December 2018; pp. 1081-1086.

127. Lahmiri, S. Comparing Variational and Empirical Mode Decomposition in Forecasting Day-Ahead Energy Prices. IEEE Syst. J. 2017, 11, 1907-1910. [CrossRef]

128. Varshney, H.; Sharma, A.; Kumar, R. A hybrid approach to price forecasting incorporating exogenous variables for a day ahead electricity Market. In Proceedings of the 2016 IEEE 1st International Conference on Power Electronics, Intelligent Control and Energy Systems (ICPEICES), Delhi, India, 4-6 July 2016; pp. 1-6.

129. Xiao, L.; Shao, W.; Yu, M.; Ma, J.; Jin, C. Research and application of a hybrid wavelet neural network model with the improved cuckoo search algorithm for electrical power system forecasting. Appl. Energy 2017, 198, 203-222. [CrossRef]

130. Khajeh, M.G.; Maleki, A.; Rosen, M.A.; Ahmadi, M.H. Electricity price forecasting using neural networks with an improved iterative training algorithm. Int. J. Ambient. Energy 2018, 39, 147-158. [CrossRef]

131. Bisoi, R.; Dash, P.K.; Das, P.P. Short-term electricity price forecasting and classification in smart grids using optimized multikernel extreme learning machine. Neural Comput. Appl. 2018, 32, 1457-1480. [CrossRef]

132. Kim, M.K. Short-term price forecasting of Nordic power market by combination Levenberg-Marquardt and Cuckoo search algorithms. IET Gener. Transm. Distrib. 2015, 9, 1553-1563. [CrossRef]

133. Pourdaryaei, A.; Mokhlis, H.; Illias, H.A.; Kaboli, S.H.A.; Ahmad, S. Short-Term Electricity Price Forecasting via Hybrid Backtracking Search Algorithm and ANFIS Approach. IEEE Access 2019, 7, 77674-77691. [CrossRef]

134. Ebrahimian, H.; Barmayoon, S.; Mohammadi, M.; Ghadimi, N. The price prediction for the energy market based on a new method. Econ. Res.-Ekon. Istraživanja 2018, 31, 313-337. [CrossRef]

135. Abedinia, O.; Amjady, N.; Shafie-Khah, M.; Catalão, J. Electricity price forecast using Combinatorial Neural Network trained by a new stochastic search method. Energy Convers. Manag. 2015, 105, 642-654. [CrossRef]

136. Ghayekhloo, M.; Azimi, R.; Ghofrani, M.; Menhaj, M.; Shekari, E. A combination approach based on a novel data clustering method and Bayesian recurrent neural network for day-ahead price forecasting of electricity markets. Electr. Power Syst. Res. 2019, 168, 184-199. [CrossRef]

137. Itaba, S.; Mori, H. An Electricity Price Forecasting Model with Fuzzy Clustering Preconditioned ANN. Electr. Eng. Jpn. 2018, 204, 10-20. [CrossRef]

138. Ghofrani, M.; Azimi, R.; Najafabadi, F.M.; Myers, N. A new day-ahead hourly electricity price forecasting framework. In Proceedings of the 2017 North American Power Symposium (NAPS), Morgantown, WV, USA, 17-19 September 2017; pp. 1-6. [CrossRef]

139. Itaba, S.; Mori, H. A Fuzzy-Preconditioned GRBFN Model for Electricity Price Forecasting. Procedia Comput. Sci. 2017, 114, 441-448. [CrossRef]

140. Zhou, L.; Wang, B.; Wang, Z.; Wang, F.; Yang, M. Seasonal classification and RBF adaptive weight based parallel combined method for day-ahead electricity price forecasting. In Proceedings of the 2018 IEEE Power \& Energy Society Innovative Smart Grid Technologies Conference (ISGT), Washington, DC, USA, 19-22 February 2018; pp. 1-5.

141. Naz, A.; Javed, M.U.; Javaid, N.; Saba, T.; Alhussein, M.; Aurangzeb, K. Short-Term Electric Load and Price Forecasting Using Enhanced Extreme Learning Machine Optimization in Smart Grids. Energies 2019, 12, 866. [CrossRef]

142. Baldick, R. Wind and Energy Markets: A Case Study of Texas. IEEE Syst. J. 2011, 6, 27-34. [CrossRef]

143. Bell, W.P.; Wild, P.; Foster, J.; Hewson, M. Revitalising the wind power induced merit order effect to reduce wholesale and retail electricity prices in Australia. Energy Econ. 2017, 67, 224-241. [CrossRef]

144. Blakers, A.; Stocks, M.; Lu, B.; Cheng, C. The observed cost of high penetration solar and wind electricity. Energy 2021, 233, 121150. [CrossRef]

145. Cutler, N.J.; Boerema, N.D.; MacGill, I.F.; Outhred, H.R. High penetration wind generation impacts on spot prices in the Australian national electricity market. Energy Policy 2011, 39, 5939-5949. [CrossRef]

146. Denny, E.; Tuohy, A.; Meibom, P.; Keane, A.; Flynn, D.; Mullane, A.; O’Malley, M. The impact of increased interconnection on electricity systems with large penetrations of wind generation: A case study of Ireland and Great Britain. Energy Policy 2010, 38, 6946-6954. [CrossRef]

147. Elfarra, M.A.; Kaya, M. Estimation of electricity cost of wind energy using Monte Carlo simulations based on nonparametric and parametric probability density functions. Alex. Eng. J. 2021, 60, 3631-3640. [CrossRef]

148. Khosravi, M.; Afsharnia, S.; Farhangi, S. Stochastic power management strategy for optimal day-ahead scheduling of wind-HESS considering wind power generation and market price uncertainties. Int. J. Electr. Power Energy Syst. 2022, 134, 107429. [CrossRef]

149. Ji, Y.; Xu, Q.; Zhao, J.; Yang, Y.; Sun, L. Day-ahead and intra-day optimization for energy and reserve scheduling under wind uncertainty and generation outages. Electr. Power Syst. Res. 2021, 195, 107133. [CrossRef] 
150. Liu, T.; Xu, J. Equilibrium strategy based policy shifts towards the integration of wind power in spot electricity markets: A perspective from China. Energy Policy 2021, 157, 112482. [CrossRef]

151. Niromandfam, A.; Yazdankhah, A.S.; Kazemzadeh, R. Modeling demand response based on utility function considering wind profit maximization in the day-ahead market. J. Clean. Prod. 2020, 251, 119317. [CrossRef]

152. Perez, A.; Garcia-Rendon, J.J. Integration of non-conventional renewable energy and spot price of electricity: A counterfactual analysis for Colombia. Renew. Energy 2021, 167, 146-161. [CrossRef]

153. Akdag, S.A.; Bagiorgas, H.; Mihalakakou, G. Use of two-component Weibull mixtures in the analysis of wind speed in the Eastern Mediterranean. Appl. Energy 2010, 87, 2566-2573. [CrossRef]

154. Ordoudis, C.; Pinson, P.; Morales, J.M.; Zugno, M. An Updated Version of the IEEE RTS 24-Bus System for Electricity Market and Power System Operation Studies; Technical University of Denmark: Kongens Lyngby, Denmark, 2016.

155. Amjady, N.; Hemmati, M. Energy price forecasting-Problems and proposals for such predictions. IEEE Power Energy Mag. 2006, 4, 20-29. [CrossRef]

156. International Energy Agency. Electricity Market Report. Available online: www.iea.org (accessed on 1 September 2021).

157. Zhao, Z.; Wang, C.; Nokleby, M.; Miller, C.J. Improving short-term electricity price forecasting using day-ahead LMP with ARIMA models. In Proceedings of the 2017 IEEE Power \& Energy Society General Meeting, Chicago, IL, USA, 16-20 July 2017 ; pp. 1-5.

158. Lin, W.-M.; Gow, H.-J.; Tsai, M.-T. An enhanced radial basis function network for short-term electricity price forecasting. Appl. Energy 2010, 87, 3226-3234. [CrossRef]

159. Wang, L.; Zhang, Z.; Chen, J. Short-Term Electricity Price Forecasting With Stacked Denoising Autoencoders. IEEE Trans. Power Syst. 2016, 32, 2673-2681. [CrossRef]

160. Yan, X.; Chowdhury, N.A. Mid-term electricity market clearing price forecasting: A multiple SVM approach. Int. J. Electr. Power Energy Syst. 2014, 58, 206-214. [CrossRef]

161. Sahay, K.B.; Bhushan, S.K. One hour ahead price forecast of Ontario electricity market by using ANN. In Proceedings of the 2015 International Conference on Energy Economics and Environment (ICEEE), Greater Noida, India, 27-28 March 2015; pp. 1-6.

162. He, K.; Yu, L.; Tang, L. Electricity price forecasting with a BED (Bivariate EMD Denoising) methodology. Energy 2015, 91, 601-609. [CrossRef]

163. Qiu, X.; Suganthan, P.; Amaratunga, G.A. Short-term Electricity Price Forecasting with Empirical Mode Decomposition based Ensemble Kernel Machines. Procedia Comput. Sci. 2017, 108, 1308-1317. [CrossRef] 